\title{
The opportunity of membrane technology for hydrogen purification in the power to hydrogen (P2H) roadmap: a review
}

\author{
Hiep Thuan Lu $(\bowtie)^{1,2,3}$, Wen Li $^{1}$, Ehsan Soroodan Miandoab ${ }^{1}$, Shinji Kanehashi ${ }^{4}$, Guoping Hu (凶) ${ }^{1,5}$ \\ 1 Department of Chemical Engineering, The University of Melbourne, Parkville, VIC 3010, Australia \\ 2 Department of Animal, Plant and Soil Sciences, La Trobe University, Bundoora, VIC 3086, Australia \\ 3 Australian Research Council (ARC) Research Hub for Medicinal Agriculture, La Trobe University, Bundoora, VIC 3086, Australia \\ 4 Graduate School of Engineering, Tokyo University of Agriculture and Technology, Tokyo 184-8588, Japan \\ 5 Fluid Science \& Resources Division, Department of Chemical Engineering, the University of Western Australia, Crawley, WA 6009, Australia
}

(C) Higher Education Press 2020

\begin{abstract}
The global energy market is in a transition towards low carbon fuel systems to ensure the sustainable development of our society and economy. This can be achieved by converting the surplus renewable energy into hydrogen gas. The injection of hydrogen $(\leqslant 10 \% \mathrm{v} / \mathrm{v})$ in the existing natural gas pipelines is demonstrated to have negligible effects on the pipelines and is a promising solution for hydrogen transportation and storage if the enduser purification technologies for hydrogen recovery from hydrogen enriched natural gas (HENG) are in place. In this review, promising membrane technologies for hydrogen separation is revisited and presented. Dense metallic membranes are highlighted with the ability of producing 99.9999999\% (v/v) purity hydrogen product. However, high operating temperature $\left(\geqslant 300^{\circ} \mathrm{C}\right)$ incurs high energy penalty, thus, limits its application to hydrogen purification in the power to hydrogen roadmap. Polymeric membranes are a promising candidate for hydrogen separation with its commercial readiness. However, further investigation in the enhancement of $\mathrm{H}_{2} / \mathrm{CH}_{4}$ selectivity is crucial to improve the separation performance. The potential impacts of impurities in HENG on membrane performance are also discussed. The research and development outlook are presented, highlighting the essence of upscaling the membrane separation processes and the integration of membrane technology with pressure swing adsorption technology.
\end{abstract}

Keywords power to hydrogen, membrane technology, hydrogen, energy

Received April 18, 2020; accepted July 5, 2020

E-mails: H.lu@latrobe.edu.au (Lu H T); guoping.hu@unimelb.edu.au (Hu G)

\section{Introduction}

\subsection{Energy outlook to 2040}

Energy plays a crucial role in the global economy growth. From the BP Energy Outlook [1], world population will reach 9.2 billion in 2040 and the global gross product is proposed to grow $3.2 \%$ per annum in the 2017-2040 period assuming that government policies, technology development and social preferences will remain at the current pace and manner of evolution. The expansion of world economy will drive the global energy demand by an increase of $0.8 \%-1.2 \%$ per annum with $16.4-17.9$ Gtoe (gigatonnes of oil equivalent) of primary energy consumption in 2040 [1].

Although energy demand fluctuates with major changes in global economy or our society [2], it is clear that the overall global energy demand tends to increase from a long term perspective. The global energy consumption showed recovery from the 2008 global economy crisis [2], however, the outbreak of the severe acute respiratory syndrome coronavirus 2 (SARS-CoV-2) in 2019-2020 added extra uncertainty to the fuel demand. The recent Global Oil Demand Report published by International Energy Agency (IEA) predicts that the global oil demand will drop by 90000 barrels per day in 2020 in comparison with that in 2019 [3]. However, with the SARS-CoV-2 being under control in China, which accounts for more than $80 \%$ of the global oil demand growth in 2019 , the global oil demand will rebound in 2021 and grow by 5.7 million barrels per day over 2019-2025 [3].

One of the greatest challenges for the energy system is to meet the fast-growing energy demand simultaneously with less or no greenhouse gas emissions, which is the major driver for climate change. The breakdown of primary 
energy consumption in 2017 (Fig. 1) shows that traditional energy sources such as coal, oil and gas remain to be the major fuels in the global energy market [1]. The production and consumption of fossil fuels produce anthropogenic greenhouse gas. The global plans set out in the 2015 at the United Nations Conference of the Parties targeted at an increase of global average temperature to be well below $1.5^{\circ} \mathrm{C}$ by 2050 via effective carbon mitigation approaches etc. [4]. One major approach is carbon capture, utilization and storage (CCUS), which utilises gas separation technologies, such as solvent absorption, membrane separation and adsorption, to capture the $\mathrm{CO}_{2}$ from the processing gas streams and then either converts the captured $\mathrm{CO}_{2}$ into fuels or chemicals [5,6], or stores it underground in geological reservoirs safely and permanently [7]. Globally, 37 large-scale CCUS projects are operating, commissioning or in progress with a total $\mathrm{CO}_{2}$ capture capacity of $65 \mathrm{Mt}$ per annum (mega tons per annum) $[5,8]$. Another approach for carbon removal and storage is bioenergy with carbon capture and storage, which uses biomass to produce energy for CCUS facilities and the whole process results in negative net $\mathrm{CO}_{2}$ emission [6]. However, both technologies require extremely high capital investment, land footprint and energy consumption [9]. Hence, many other proposals have been made to decarbonise the energy sector such as implementing more renewables, developing better energy storage systems and enhancing energy usage efficiency [1].

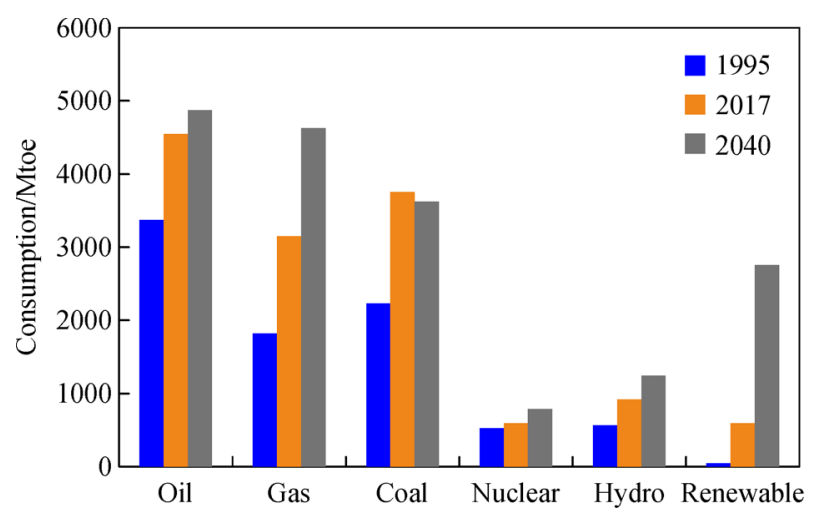

Fig. 1 The breakdown of primary energy consumption by fuel in 1995, 2017 and an outlook to 2040 based on the Evolving transition scenario (Renewable includes wind, biomass, solar, biofuels and geothermal) [1]. Source: BP Energy Outlook 2019. Adapted with permission.

\subsection{Renewables}

Renewables, such as wind, solar, hydro, biomass and geothermal energy, is expected to play a key role in the clean energy transition process $[1,10,11]$. The IEA estimated that the share of renewables in primary energy consumption would be $12.4 \%$ by 2023 (Fig. 2) [11]. Generally, the renewables are abundant to meet the global energy demand, however, their deployment highly relies on the readiness of energy generation, transportation and storage infrastructures and technologies. For instance, the net global wave energy is around 2-3 terawatt [12] which approximates to the global electricity consumption in 2018 [13]. However, the fluid corrosion and the voltage limit in electricity grid (i.e., $\pm 10 \%$ of the nominal value) [14] to resist the fluctuation of renewable energy supply in accordance with weather change are some of the challenges to overcome for deploying the wave energy in large scale. Similarly, wind and solar energy are experiencing a gap in electricity supply between daytime and nighttime and among seasons resulting in the waste of surplus electricity due to the lack of energy storage solutions [15].

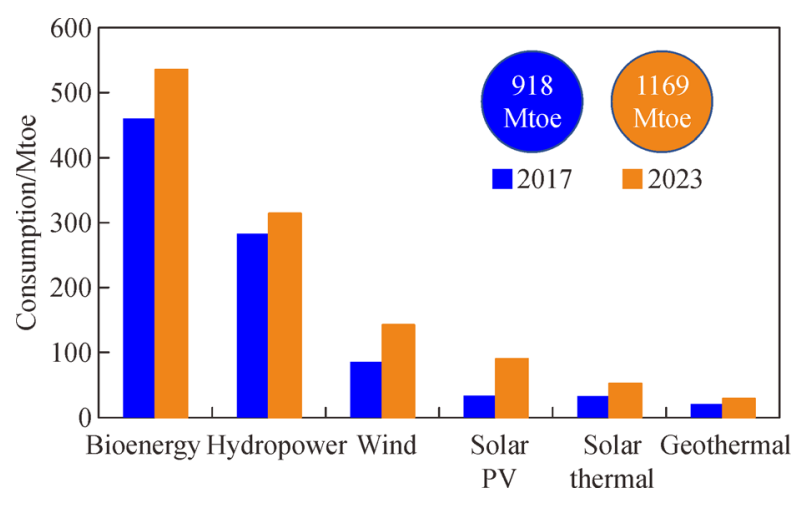

Fig. 2 The consumption of renewable energy categorised by technology in 2017 and an outlook to 2023 [11]. Source: IEA (2018). Market Report Series: Renewables 2018: Analysis and Forecasts to 2023, All rights reserved. As modified by Lu et al.

\subsection{Power to hydrogen $(\mathrm{P} 2 \mathrm{H})$}

One approach to enhance the storage and reserve the production capacity of renewable energy is the power to hydrogen $(\mathrm{P} 2 \mathrm{H})$ process chain, in which surplus electricity is used to convert water to $\mathrm{H}_{2}$ via technologies such as alkaline electrolysis [16], proton exchange membrane electrolysis [17] and solid oxide electrolysis [18], thereafter, hydrogen can be transported and consumed by endusers for combustion, carbon hydrogenation or methanation etc. [19]. Hydrogen is preferable for renewable energy storage due to its higher mass energy density $(142 \mathrm{MJ} \cdot \mathrm{kg}$ $\left.{ }^{1}\right)$ in comparison with other fuels such as natural gas and gasoline (energy density at around $40-60 \mathrm{MJ} \cdot \mathrm{kg}^{-1}$ ) [20]. Hydrogen can also be used in several industries such as hydrocarbon reforming and ammonia synthesis [21]. The minimum hydrogen purity requirements in fuel gas, polymer electrolyte fuel cells and rocket engine fuel industries are 54\%-60\% (v/v), 99.97\% (v/v) and $99.999999 \%(\mathrm{v} / \mathrm{v})$, respectively [22,23]. The major challenge for hydrogen transportation and storage is its low volumetric density and the possibility of hydrogeninduced fracture on the pipelines and storage facilities 
[24,25]. Around $88 \%$ of reported hydrogen projects utilised compressed gas tanks for storage and a minority utilised metal hydrides storage [24].

The recent cost assessment for hydrogen delivery pathways suggested that the pipeline networks is the most cost effective and environmental-friendly approach for large scale hydrogen stations (around $80000 \mathrm{~kg}$ hydrogen capacity required per day) [26]. However, the construction of hydrogen distribution pipelines can cost USD $320-1000$ per metre for the $20-61 \mathrm{~cm}$ pipelines at 68 bars [27,28], which is at least $10 \%$ more expensive than natural gas pipelines [27,29].

A more cost-effective option for hydrogen transport, especially in the market development phase, is to inject hydrogen into the existing natural gas pipelines [30] as the global natural gas pipelines are well built and distributed (>2.7 million kilometres in 2016) [31]. However, since the traditional natural gas pipelines are commonly made of ferritic stainless steel (SS) [32], plastic and cast iron [33], the suggested hydrogen injection concentration in natural gas pipelines is $6 \%-10 \%(\mathrm{v} / \mathrm{v})$ at up to 40 bar pipeline pressure $[34,35]$ to minimise the ignition risks, leakage issues and pipeline fatigues [30,36].

The hydrogen/natural gas mixture, also called hydrogen enriched natural gas (HENG), can be utilised directly for power generation [30] and household appliances [37]. However, the increasing displacement of hydrogen in natural gas stream will lower the heating value of gas mixture [38]. In fact, HENG could be used as a carrier to transport hydrogen from production sites to the renewable energy end users if the technologies for purifying hydrogen from HENG are in place.

Studies on hydrogen separation from methane reformed off gas and syngas have been reported extensively in literature $[15,30,39,40]$. These gas streams, however, commonly have $10 \%-80 \%$ (v/v) $\mathrm{H}_{2}, 2 \%-30 \%$ (v/v) $\mathrm{CO}_{2}$ and up to $60 \%(\mathrm{v} / \mathrm{v}) \mathrm{N}_{2}$ in balance of methane $[15,30,39,41]$ while the HENG is a $\mathrm{H}_{2} / \mathrm{CH}_{4}$ mixture with up to $15 \%(\mathrm{v} / \mathrm{v}) \mathrm{H}_{2}$ and less than $2 \%-4 \%$ (v/v) $\mathrm{CO}_{2}$ [30]. There are very few investigations on hydrogen recovery from HENG at low temperature (e.g., ambient temperature). Therefore, the development of high efficiency and cost-effective technologies for the recovery of $\mathrm{H}_{2}$ from its low concentration streams is a key to extend the $\mathrm{P} 2 \mathrm{H}$ technology.

Membrane technology is one of the most proven economically viable approach for gas separation and has been commercialised in natural gas sweetening [42] and hydrogen recovery from ammonia purge gas [43] since 1980s. Recently, membrane technology is also implemented in carbon capture studies $[44,45]$ and plasma technology to convert $\mathrm{N}_{2}$ and $\mathrm{CO}_{2}$ into value-added chemicals $[46,47]$. The advantages of membrane technology in comparison with other hydrogen separation technologies such as cryogenic distillation and pressure swing adsorption (PSA) processes are having high energy efficiency, high surface area-to-volume ratio [41], low environmental impact $[41,48,49]$ and potential to achieve high purity hydrogen $(>99.5 \%(\mathrm{v} / \mathrm{v}))[30,40,48,50]$.

Several review articles have been published to assess the role of membrane separation technology in hydrogen purification. For instance, Adhikari and Fernando reviewed the use of different membrane types, mainly focusing on inorganic membranes, in hydrogen separation from hydrogen-rich gas streams [40]. The relationships of structure and property of membranes and hydrogen separation ability was also reported by Ockwig and Nenoff [51]. In addition, a book chapter about the advances in hydrogen separation and purification using membrane technology was also presented by Zornoza et al. that summarised the hydrogen separation performance of different membrane materials and membrane reactors [50]. A comparison between $\mathrm{H}_{2}$-selective membranes and $\mathrm{CO}_{2}$-selective membranes for hydrogen purification was also reported [49]. However, most of these reviews targeted at steam reforming of hydrocarbons that contained high hydrogen concentration (up to $80 \%(\mathrm{v} / \mathrm{v})$ in the balance of $\mathrm{CO}_{2}$ and minor $\mathrm{CH}_{4}$ ) at high temperature $\left(>350{ }^{\circ} \mathrm{C}\right)[50,51]$. Hence, the scope of this review is to critically assess the role of membrane technologies for hydrogen recovery from HENG and highlight its potential in the $\mathrm{P} 2 \mathrm{H}$ pathway.

\section{Membrane for hydrogen separation}

\subsection{Fundamental of hydrogen transport in membranes}

A membrane is a barrier that selectively separates some components from a mixture based on the physical nature of penetrants and the interactions between penetrants and penetrant-membrane $[49,50]$. The transport mechanism of $\mathrm{H}_{2}$ and $\mathrm{CH}_{4}$ through membranes varies depending upon the membrane types and generally follows one or a combination of the following 4 mechanisms: Knudsen diffusion, surface diffusion, molecular sieving and solution-diffusion model (Fig. 3) [40,49,50,52,53]. Knudsen diffusion applies when the mean free path of penetrant (i.e., the average travelling distance of a penetrant molecule inside the pores) is larger than the pore diameter $[52,54]$. The gas selectivity via the Knudsen mechanism is proportional to the inverse square root ratio of the molecular weight of transported gases (i.e., Selectivity A/B $\propto \sqrt{\frac{\text { Molecular weight of component } \mathrm{B}}{\text { Molecular weight of component } \mathrm{A}}}$ ) [54]. This ratio for $\mathrm{H}_{2} / \mathrm{CH}_{4}$ systems is 2.8 that is not attractive in commercial scale due to the low gas selectivity [52].

The diffusion of hydrogen through the membrane could be enhanced if the gas molecules absorbed on the pore surface, which is defined as surface diffusion [55]. This mechanism is mainly applied in porous membranes 

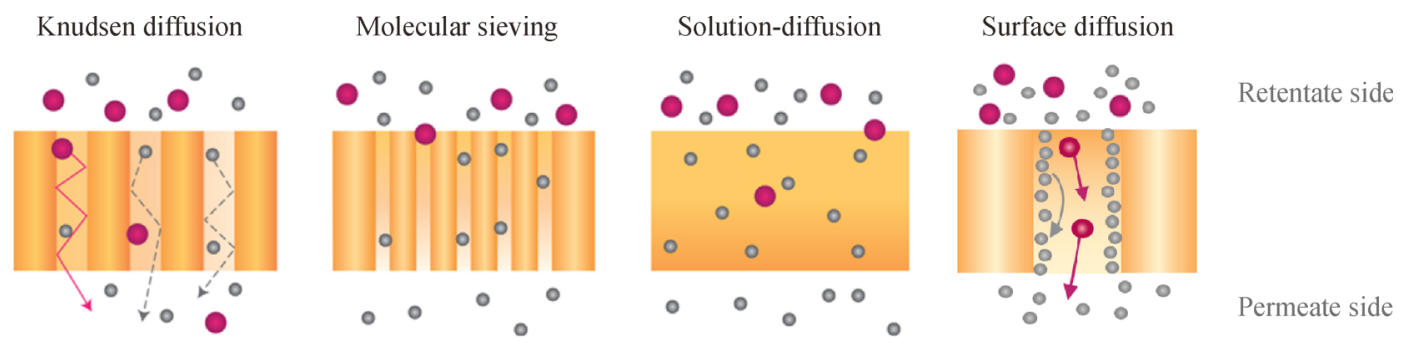

Fig. 3 The penetration mechanism of penetrants through membranes. Photo courtesy of CO2CRC.

[40,56]. When the pore size of membranes and kinetic diameter of penetrants are similar, the gas transport primarily follows the molecular sieving mechanism. According to the kinetic diameters of $\mathrm{H}_{2}$ and $\mathrm{CH}_{4}$ (Table 1), the preferred pore diameter for the separation of $\mathrm{H}_{2}$ from HENG is between 2.89 and $3.80 \AA$ such as ultra-microporous membranes [52].

Table 1 Physical properties of hydrogen and methane gas molecules [57]

\begin{tabular}{lccc}
\hline Item & $\begin{array}{c}\text { Molecular weight } \\
/\left(\mathrm{g} \cdot \mathrm{mol}^{-1}\right)\end{array}$ & $\begin{array}{c}\text { Kinetic diameter } \\
/ \AA\end{array}$ & $\begin{array}{c}\text { Critical temperature } \\
/ \mathrm{K}\end{array}$ \\
\hline $\mathrm{H}_{2}$ & 2 & 2.89 & 33.24 \\
$\mathrm{CH}_{4}$ & 16 & 3.80 & 191.05 \\
\hline
\end{tabular}

The widely-accepted mechanism of gas transport in polymeric and dense metallic membranes is solutiondiffusion. This mechanism typically involves three steps: 1) the penetrants dissolve into the membrane on the feed side; 2) diffuse through the membrane; 3 ) desorb on the permeate side of the membrane [41,52]. The permeation and selectivity of $\mathrm{H}_{2} / \mathrm{CH}_{4}$ by solution-diffusion mechanism rely on the solubility and diffusivity of penetrants in the membrane [43].

The driving force for gas permeation through membranes is the chemical potential difference of $\mathrm{H}_{2}$ and $\mathrm{CH}_{4}$ on the two sides of the membrane, which is mainly in the form of gas partial pressure. The performance of $\mathrm{H}_{2} / \mathrm{CH}_{4}$ separation membrane can be expressed in term of permeance $(Q)$ or permeability $(P)$ of hydrogen and selectivity $(\alpha)$ of $\mathrm{H}_{2}$ versus $\mathrm{CH}_{4}$ (Eqs. (1) and (2)). The hydrogen permeability in metallic membrane follows the Sievert's law (Eq. (3)) with the flux being dependent on pressure exponent ' $n$ ' at around 0.5 [58]. The hydrogen separation efficiency is often limited by the pressure ratio across the membrane as shown in Eq. (4) [59], which is not a barrier for hydrogen purification from HENG stream as its operation pressure can be as high as 68 bar [30].

$$
\begin{gathered}
P_{i}=Q_{i} l=\frac{J_{i} l}{\left(p_{i, \text { feed }}-p_{i, \text { permeate }}\right)}, \\
\alpha_{\mathrm{H}_{2} / \mathrm{CH}_{4}}=\frac{P_{\mathrm{H}_{2}}}{P_{\mathrm{CH}_{4}}},
\end{gathered}
$$

where $Q$ is the gas permeance of gas component $i$ (e.g., $\mathrm{H}_{2}$ or $\left.\mathrm{CH}_{4}\right) ; l$ is the membrane thickness; $J$ is the gas flux (flowrate per membrane area); $p_{i \text {,feed }}$ and $p_{i \text {,permeate }}$ are partial pressure of gas component $i$ in the feed and permeate sides of the membrane, respectively.

$$
P_{\mathrm{H}_{2}}=\frac{J_{\mathrm{H}_{2}} \cdot l}{\left(p_{\mathrm{H}_{2}, \text { feed }}^{n}-p_{\mathrm{H}_{2}, \text { permeate }}^{n}\right)},
$$

$$
\frac{\text { Feed pressure }}{\text { Permeate pressure }} \geqslant \frac{\mathrm{H}_{2} \text { concentration in permeate }}{\mathrm{H}_{2} \text { concentration in feed }} \text {. }
$$

\subsection{Dense metallic membranes}

Several types of membranes have been extensively studied for hydrogen separation including dense metallic membranes, porous inorganic membranes, metal organic membranes and polymeric membranes. Among these, dense metallic membranes have attracted great interests due to their high hydrogen selectivity and commercial availability $[50,60]$. In the presence of catalytic membrane surfaces, hydrogen is transported through the membrane in form of proton, hydride ion or neutral atoms [50]. This mechanism is unique for hydrogen and cannot occur for other gas components in HENG like $\mathrm{CH}_{4}$ and $\mathrm{CO}_{2}$, therefore, the hydrogen purity in metallic membranes can reach up to $99.9999999 \%$ (v/v) [30].

Pd membranes are the most common metallic membranes for hydrogen separation with hydrogen permeability on the order of 1000 times greater than other metals such as Fe, Ni and Pt [61]. Several studies (Table 2) on the $\mathrm{Pd}$ membranes showed that the $\mathrm{H}_{2} / \mathrm{CH}_{4}$ selectivity could be extremely high $(\geqslant 1000)$. However, there are some challenges for using the Pd membranes such as low mechanical resistance of the membrane in high pressure and the poison effects of impurities such as $\mathrm{H}_{2} \mathrm{~S}$ and $\mathrm{CO}$ in the feed gas $[50,62,63]$. An effective method to increase the hydrogen recovery is depositing thin Pd membranes on the supports such as Vycor glass [64,65], ceramics [66,67], porous alumina $[68,69]$ or SS [69-71]. This is because thinner membrane enhances the hydrogen flux (Eq. (3)) while the support increases the mechanical strength of 
Table 2 A shortlist of palladium membranes for hydrogen separation

\begin{tabular}{|c|c|c|c|c|c|c|}
\hline $\begin{array}{l}\text { Membrane material } \\
\text { /support }\end{array}$ & $\begin{array}{l}\text { Preparation } \\
\text { method }^{\text {a) }}\end{array}$ & $\begin{array}{c}\text { Thickness of } \\
\text { active layer/ } / \mu \mathrm{m}\end{array}$ & $\begin{array}{l}\text { Experiment } \\
\text { conditions }\end{array}$ & $\begin{array}{l}\text { Hydrogen permeance } \\
/\left(\mathrm{mol} \cdot \mathrm{m}^{-2} \cdot \mathrm{s}^{-1} \cdot \mathrm{Pa}^{-1}\right)\end{array}$ & $\begin{array}{c}\text { Hydrogen } \\
\text { selectivity b) }\end{array}$ & Ref. \\
\hline$\overline{\mathrm{Pd} / \mathrm{SS}^{\text {a) }}}$ & $\overline{\text { ELP }}$ & 3.5 & $\begin{array}{c}3.5 \mathrm{bar} \\
500{ }^{\circ} \mathrm{C}-550{ }^{\circ} \mathrm{C}\end{array}$ & $1.7-9.4 \times 10^{-7}$ & $\infty$ & {$[71]$} \\
\hline $\mathrm{Pd} / \mathrm{PPO}$ polymer ${ }^{\text {a) }}$ & ELP & 5 & $\begin{array}{c}1 \mathrm{bar} \\
500^{\circ} \mathrm{C}\end{array}$ & $1 \times 10^{-6}$ & $\infty$ & [96] \\
\hline $\mathrm{Pd} / \alpha-\mathrm{Al}_{2} \mathrm{O}_{3}$ & MOCVD & 2 & $\begin{array}{c}1-2 \text { bar } \\
300^{\circ} \mathrm{C}-500{ }^{\circ} \mathrm{C}\end{array}$ & $1 \times 10^{-6}$ & 1000 & {$[68]$} \\
\hline $\mathrm{Pd} / \alpha-\mathrm{Al}_{2} \mathrm{O}_{3}$ & ELP & 0.9 & $\begin{array}{l}1.1 \text { bar } \\
500{ }^{\circ} \mathrm{C}\end{array}$ & $4 \times 10^{-6}$ & 9200 & [69] \\
\hline $\mathrm{Pd} / \mathrm{YSZ} / \mathrm{SS}$ & ELP & 27.7 & $\begin{array}{c}4 \mathrm{bar} \\
350^{\circ} \mathrm{C}-450^{\circ} \mathrm{C}\end{array}$ & $1.5 \times 10^{-7}$ & $\infty$ & {$[78]$} \\
\hline Pd-Ag alloy $/ \alpha-\mathrm{Al}_{2} \mathrm{O}_{3}$ & ELP & 11 & $\begin{array}{c}4 \text { bar } \\
550{ }^{\circ} \mathrm{C}\end{array}$ & $1.3 \times 10^{-6}$ & $1000-10000$ & {$[76]$} \\
\hline $\mathrm{Pd}-\mathrm{Cu}$ alloy & ELP & 7.2 & $\begin{array}{l}2.2 \mathrm{bar} \\
400^{\circ} \mathrm{C}\end{array}$ & $1.4 \times 10^{-6}$ & 40000 & [77] \\
\hline
\end{tabular}

a) Metal-organic chemical vapor deposition (MOCVD), Electroless plating (ELP), poly(2,6-dimethyl-1,4-phenylene oxide) (PPO); b) due to the limited application of metallic membrane in literature, the hydrogen selectivity is based on $\mathrm{H}_{2} / \mathrm{N}_{2}$ system. However, in the solution-diffusion mechanism, the transportation behaviour of $\mathrm{N}_{2}$ and $\mathrm{CH}_{4}$ through the membrane are proved to be identical [57]. Hence, the trends of $\mathrm{H}_{2} / \mathrm{N}_{2}$ and $\mathrm{H}_{2} / \mathrm{CH}_{4}$ selectivity are proposed to be identical.

membranes. In addition, the mechanical strength of the membrane has been successfully increased by incorporating Pd with other metals in group IB, IVB, VB and VIB of the periodic table to form alloy membranes without affecting the $\mathrm{H}_{2}$ selectivity of the membrane [72-78].

It should be noted that low operating temperatures $\left(\leqslant 300{ }^{\circ} \mathrm{C}\right)$ lead to hydrogen-induced embrittlement phenomenon in $\mathrm{Pd}$ membranes [49,79], which limits its application significantly. Another barrier restricting the application of metallic membranes is the high cost of membrane materials $[51,80]$. Although several palladium membrane modules have been introduced in industrial scale, premium in steam methane reforming and water-gas shift industry (e.g., the Pd alloy Micro-Channel ${ }^{\mathrm{TM}}$ Technology (Power \& Energy Inc., USA [81]), the Hysep ${ }^{\circledR}$ module (Energy Research Centre of Netherland [82]) and the twostep process of Pd-based membrane module (SINTEF, Norway [82])), dense metallic membranes are not particularly suitable for the purpose of separating hydrogen from HENG pipelines at low temperatures.

2.3 Ceramic mixed protonic-electronic conducting membranes

Dense ceramic mixed protonic-electronic conducting membranes have been intensively studied for hydrogen separation with advantages including high mechanical stability and lower manufacturing cost than dense metallic membranes $[83,84]$. The $\mathrm{H}_{2}$ transport through dense ceramic proton conducting membranes follows solutiondiffusion mechanism $[85,86]$, in which $\mathrm{H}_{2}$ in the feed gas diffuses through the membrane in form of $\mathrm{H}^{+}$along with the electrons. The flux of hydrogen can be described by the Wagner theory as shown in Eq. (5) [87].

$$
J_{\mathrm{H}_{2}}=-\frac{\mathrm{R} T}{2 F^{2} l} \int_{\text {Feed }}^{\text {Permeate }}\left(\sigma_{\mathrm{H}^{+}} \times t_{\mathrm{e}^{-}}\right) d \ln p_{\mathrm{H}_{2}},
$$

where $J_{\mathrm{H}_{2}}$ is the $\mathrm{H}_{2}$ flux; $R$ is the universal gas constant; $T$ is the absolute temperature; $F$ is the Faraday constant; $l$ is the membrane thickness; $\sigma_{\mathrm{H}^{+}}$is the proton conductivity; $t_{\mathrm{e}^{-}}$is the electronic transport number and $p_{\mathrm{H}_{2}}$ is partial pressure of $\mathrm{H}_{2}$.

These ceramic materials, such as perovskite-type oxides, pyrochlores, niobates, tantalates and tungstates, often have a large number of protons and high electronic conductivity [88]. The crystal structures of these ceramic materials have been well studied in the literature [88,89]. Perovskites based oxides (e.g., $\mathrm{BaCeO}_{3}, \mathrm{SrZrO}_{3}$ and $\mathrm{SrCeO}_{3}$ ) are the most common proton conducting materials with proton conductivity in range of $10^{-3}-10^{-2} \mathrm{~S} \cdot \mathrm{cm}^{-1}\left(400{ }^{\circ} \mathrm{C}-\right.$ $1000{ }^{\circ} \mathrm{C}$ ) [90]. Various methods have been applied to enhance the proton conductivity to achieve high $\mathrm{H}_{2}$ flux, for instance, the doping of trivalent ions (i.e., $\mathrm{Yb}$ and $\mathrm{Y}$ ) into perovskites to partially replace tetravalent ions (i.e., $\mathrm{Ce}$ and $\mathrm{Zr}$ ) [91-93] and the doping of $\mathrm{Ca}$ (II) into $\mathrm{La}_{2} \mathrm{Zr}_{2} \mathrm{O}_{7-\delta}$ pyrochlores [94]. Another approach is dispersing metallic materials (i.e., $\mathrm{Pd}, \mathrm{Pt}$ and $\mathrm{Ni}$ ) into ceramic matrix (called cermet) or combining two ceramic proton conducting materials to form a composite membrane (called cercer) $[86,88]$.

A range of ceramic mixed protonic-electronic conducting membranes has been highlighted in Table 3 to address their performance for hydrogen separation. The fabrication techniques of these membranes are similar to metallic membranes, with $\geqslant 20 \mu \mathrm{m}$ in membrane thickness and $10^{-8}-10^{-9} \mathrm{~mol} \cdot \mathrm{m}^{-2} \cdot \mathrm{Pa}^{-1} \cdot \mathrm{s}^{-1}$ in hydrogen permeance $[83,95]$. However, the major drawback of this type of membranes is the requirement of high temperature for hydrogen separation. The hydrogen conductivities of most 
Table 3 A shortlist of ceramic mixed protonic-electronic conducting membranes for hydrogen separation

\begin{tabular}{|c|c|c|c|c|c|c|c|}
\hline Membrane & Type & $\begin{array}{c}\text { Thickness of active } \\
\text { layer/mm }\end{array}$ & Temperature $/{ }^{\circ} \mathrm{C}$ & Feed gas & $\begin{array}{c}\text { Sweep } \\
\text { gas }\end{array}$ & $\begin{array}{c}\text { Hydrogen flux } \\
/\left(10^{-4} \mathrm{~mol} \cdot \mathrm{m}^{-2} \cdot \mathrm{s}^{-1}\right)\end{array}$ & Ref. \\
\hline $\mathrm{BaCe}_{0.8} \mathrm{Y}_{0.2} \mathrm{O}_{3-\alpha}$ & Perovskites & 0.20 & 1050 & $25 \% \mathrm{H}_{2} / \mathrm{He}$ & $\mathrm{N}_{2}$ & 28.30 & {$[91]$} \\
\hline $\mathrm{Sr}\left(\mathrm{Ce}_{0.6} \mathrm{Zr}_{0.4}\right)_{0.85} \mathrm{Y}_{0.15} \mathrm{O}_{3-\delta}$ & Perovskites & 0.17 & 800 & Pure $\mathrm{H}_{2}$ & $\mathrm{Ar}$ & 130 & {$[92]$} \\
\hline $\mathrm{Sr}_{0.97} \mathrm{Ce}_{0.9} \mathrm{Yb}_{0.05} \mathrm{O}_{3-\delta}$ & Perovskites & 1.16 & 804 & $10 \% \mathrm{H}_{2} / \mathrm{N}_{2}$ & $\mathrm{Ar}$ & 3.30 & {$[93]$} \\
\hline $\mathrm{Nd}_{5.5} \mathrm{~W}_{0.5} \mathrm{Mo}_{0.5} \mathrm{O}_{11.25-\delta}$ & Tungstates & 0.90 & 1000 & $50 \% \mathrm{H}_{2} / \mathrm{He}$ & $\mathrm{Ar}$ & 22.30 & [97] \\
\hline $\mathrm{La}_{26.78} \mathrm{~W}_{5.22} \mathrm{O}_{55.83}$ & Tungstates & 0.03 & 1000 & $\begin{array}{c}10 \% \mathrm{H}_{2} / \mathrm{Ar} \\
2.5 \% \mathrm{H}_{2} \mathrm{O}\end{array}$ & $\mathrm{Ar}$ & 10.40 & {$[98]$} \\
\hline $\mathrm{La}_{0.5} \mathrm{Ce}_{0.5} \mathrm{O}_{2-\delta}(\mathrm{P}) / \mathrm{Ni}(\mathrm{E})^{\mathrm{a})}$ & Cermets & 0.05 & 900 & $\begin{array}{c}20 \% \mathrm{H}_{2} / \mathrm{Ar} \\
3 \% \mathrm{H}_{2} \mathrm{O}\end{array}$ & $\mathrm{Ar}$ & 6.83 & [99] \\
\hline $\mathrm{Pd}\left(\mathrm{Zr}_{0.9} \mathrm{Y}_{0.1} \mathrm{O}_{2-\delta}\right)(\mathrm{P}) / \mathrm{Pd}(\mathrm{E})$ & Cermets & 0.02 & 900 & Pure $\mathrm{H}_{2}$ & $\mathrm{~N}_{2}$ & 1410 & {$[100]$} \\
\hline $\mathrm{BaCe}_{0.95} \mathrm{~Tb}_{0.05} \mathrm{O}_{3-\delta}(\mathrm{P}) / \mathrm{Ni}(\mathrm{E})$ & Cermets & 0.09 & 850 & $50 \% \mathrm{H}_{2} / \mathrm{N}_{2}$ & $\mathrm{He}$ & 67.90 & {$[101]$} \\
\hline $\begin{array}{l}\mathrm{BaCe}_{0.65} \mathrm{Zr}_{0.2} \mathrm{Y}_{0.15} \mathrm{O}_{3-\delta}(\mathrm{P}) / \\
\mathrm{Ce}_{0.85} \mathrm{Gd}_{0.15} \mathrm{O}_{2-\delta}(\mathrm{E})\end{array}$ & Cercers & 0.65 & 755 & $50 \% \mathrm{H}_{2} / \mathrm{He}$ & $\mathrm{Ar}$ & 21.00 & {$[102]$} \\
\hline
\end{tabular}

a) $\mathrm{P} / \mathrm{E}$ : protonic phase/electronic phase.

ceramic proton conducting materials were reported to decrease by $100-1000$ times (i.e., $<10^{-5} \mathrm{~S} \cdot \mathrm{cm}^{-1}$ ) at low temperature $\left(<250{ }^{\circ} \mathrm{C}\right)$ [88]. To the best knowledge of authors, the study on $\mathrm{H}_{2} / \mathrm{CH}_{4}$ separation using this type of membranes is very rarely seen. In addition, $\mathrm{CH}_{4}$ can be dimerised on the surface of ceramic proton conducting membranes such as $\mathrm{SrCe}_{0.95} \mathrm{Yb}_{0.05} \mathrm{O}_{3-\alpha}-\mathrm{Pt}$ [89]. Hence, ceramic mixed protonic-electronic conducting membranes are not suitable for hydrogen separation from HENG.

\subsection{Inorganic microporous membranes}

Inorganic microporous membranes are commonly used for separating light gas in the mixed gas such as $\mathrm{H}_{2}$ from $\mathrm{H}_{2} /$ $\mathrm{CH}_{4}$ gas mixtures. In comparison with dense metallic membranes, inorganic microporous membranes can resist broader temperatures $\left(25^{\circ} \mathrm{C}-900{ }^{\circ} \mathrm{C}\right)$ and are more cost effective [40,50]. The flux of hydrogen $\left(J_{\mathrm{H}_{2}}\right)$ in dense metallic membranes is proportional to the square root of partial pressure of hydrogen (Eq. (3)) while $J_{\mathrm{H}_{2}}$ is proportional to partial pressure of hydrogen directly for other membrane materials (Eq. (1)). Therefore, inorganic microporous membranes are preferred to operate at high pressure of hydrogen. The $\mathrm{H}_{2}$ transport mechanism in inorganic microporous membranes is mainly molecular sieving which separates $\mathrm{H}_{2}$, the smaller kinetic diameter component, from $\mathrm{CH}_{4}$, the larger component in the mixture (Table 1). Thus, the pore diameter of porous membranes must be under $2 \mathrm{~nm}$ (e.g., microporous) to separate hydrogen effectively [50]. However, $\mathrm{H}_{2}$ may also transport through the membranes by the Knudsen diffusion mechanism in presence of defects [103]. This mechanism is less effective in $\mathrm{H}_{2}$ separation as discussed in Section 2.1 $[49,50,52]$. Therefore, the inevitable challenge for microporous membrane is to form a defect-free membrane to gain high purity hydrogen product.

\subsubsection{Zeolite membranes}

Zeolite membranes are well studied due to their strong chemical, thermal and mechanical stability. A typical zeolite membrane is built with a crystallised microporous zeolite (e.g., aluminosilicates) deposited on a porous support such as alumina, porous ceramic, SS or polymeric membranes [49]. Recent studies showed that zeolite membranes can separate $\mathrm{H}_{2}$ at various temperatures $\left(25{ }^{\circ} \mathrm{C}-700{ }^{\circ} \mathrm{C}\right)$, however, with much lower $\mathrm{H}_{2} / \mathrm{CH}_{4}$ selectivity than dense metallic membranes (Table 4). The low hydrogen selectivity might be due to the presence of inter-crystalline mesopores on the zeolite layer that were formed during the aggregation of nanocrystals [104,105]. These mesopores $(2-50 \mathrm{~nm})$ drive the gas separation towards Knudsen diffusion mechanism. Recently, some advanced fabrication techniques were studied which successfully reduced the defects in zeolite membranes in particular layer-by-layer seeding free hydrothermal synthesis $[106,107]$, catalyst cracking deposition hydrothermal synthesis [108] and functionalising the zeolite pores by amorphous materials [109]. However, these studies on zeolite membranes remain mainly in laboratory scale that will require a lot of efforts to scale up and commercialize.

\subsubsection{Silica membranes}

Silica membranes is favoured as they are often cost effective and easy to fabricate $[49,82]$. Most study on silica membrane showed high $\mathrm{H}_{2}$ permeance and selectivity (Table 5). This is due to the amorphous property of ceramic that makes it easy to form nano-scale membrane thickness and pore diameter $[49,82]$. Particularly, a silica modified membrane deposited on Vycor glass called Nanosil exhibited an outstanding $\mathrm{H}_{2} / \mathrm{CH}_{4}$ selectivity at up to 
Table 4 A shortlist of zeolite membranes for hydrogen separation

\begin{tabular}{|c|c|c|c|c|c|c|}
\hline Zeolite type/support & Synthesis method & $\begin{array}{c}\text { Thickness of } \\
\text { active layer/ } / \mu \mathrm{m}\end{array}$ & $\begin{array}{l}\text { Experiment } \\
\text { conditions }\end{array}$ & $\begin{array}{l}\text { Hydrogen permeance } \\
/\left(\mathrm{mol} \cdot \mathrm{m}^{-2} \cdot \mathrm{s}^{-1} \cdot \mathrm{Pa}^{-1}\right)\end{array}$ & $\begin{array}{c}\text { Hydrogen } \\
\text { selectivity a) }\end{array}$ & Ref. \\
\hline$\overline{\mathrm{MFI} / \text { ceramic }}$ & Hydrothermal & 3 & $\begin{array}{c}1-4 \text { bar } \\
25^{\circ} \mathrm{C}-500{ }^{\circ} \mathrm{C}\end{array}$ & $5 \times 10^{-8}$ & $4.9-7.9$ & {$[126]$} \\
\hline $\mathrm{LTA} / \alpha-\mathrm{Al}_{2} \mathrm{O}_{3}$ & $\begin{array}{l}\text { Seeding free } \\
\text { hydrothermal }\end{array}$ & 3.5 & $\begin{array}{c}1 \mathrm{bar} \\
100{ }^{\circ} \mathrm{C}\end{array}$ & $2 \times 10^{-7}$ & $5-6.5$ & {$[106$} \\
\hline $\mathrm{FAU} / \alpha-\mathrm{Al}_{2} \mathrm{O}_{3}$ & $\begin{array}{l}\text { Seeding free } \\
\text { hydrothermal }\end{array}$ & 3 & $\begin{array}{c}1 \mathrm{bar} \\
100^{\circ} \mathrm{C}\end{array}$ & $8 \times 10^{-7}$ & $3.5-5.6$ & {$[107]$} \\
\hline $\mathrm{CHA} / \alpha-\mathrm{Al}_{2} \mathrm{O}_{3}$ & Hydrothermal & $3-4$ & $\begin{array}{c}2.7 \text { bar } \\
27^{\circ} \mathrm{C}-200{ }^{\circ} \mathrm{C}\end{array}$ & $2.4 \times 10^{-8}$ & $25-10$ & {$[127]$} \\
\hline $\mathrm{La}_{2} \mathrm{NiO}_{4} \mathrm{MFI} / \alpha-\mathrm{Al}_{2} \mathrm{O}_{3}$ & Hydrothermal & 60 & $400{ }^{\circ} \mathrm{C}-700^{\circ} \mathrm{C}$ & $5.5 \times 10^{-7}$ & 9.2 & {$[128]$} \\
\hline \multirow[t]{2}{*}{$\mathrm{MFI} / \alpha-\mathrm{Al}_{2} \mathrm{O}_{3}$} & Hydrothermal & $2-3$ & $\begin{array}{c}2 \text { bar } \\
500{ }^{\circ} \mathrm{C}\end{array}$ & $5.3 \times 10^{-7}$ & 4 & {$[108]$} \\
\hline & $\begin{array}{l}\text { Hydrothermal } \\
\text { with } C C D^{b}\end{array}$ & $2-3$ & $\begin{array}{c}2 \mathrm{bar} \\
500{ }^{\circ} \mathrm{C}\end{array}$ & $3.9 \times 10^{-7}$ & 180 & \\
\hline
\end{tabular}

a) $\mathrm{H}_{2} / \mathrm{CH}_{4}$ ideal selectivity; b) CCD: catalyst cracking deposition.

Table 5 A shortlist of silica membranes for hydrogen separation

\begin{tabular}{|c|c|c|c|c|c|c|}
\hline Silica type/support & $\begin{array}{l}\text { Synthesis } \\
\text { method }\end{array}$ & $\begin{array}{c}\text { Thickness of active } \\
\text { layer } / \mathrm{nm}\end{array}$ & $\begin{array}{l}\text { Experiment } \\
\text { conditions }\end{array}$ & $\begin{array}{l}\text { Hydrogen permeance } \\
/\left(\mathrm{mol} \cdot \mathrm{m}^{-2} \cdot \mathrm{s}^{-1} \cdot \mathrm{Pa}^{-1}\right)\end{array}$ & $\begin{array}{l}\text { Hydrogen } \\
\text { selectivity }\end{array}$ & Ref. \\
\hline $\mathrm{SiO}_{2} /$ ceramic & Sol-gel & $20-30$ & $\begin{array}{c}1 \mathrm{bar} \\
100{ }^{\circ} \mathrm{C}-600{ }^{\circ} \mathrm{C}\end{array}$ & $10^{-7}$ & 2800 & {$[129]$} \\
\hline $\mathrm{CoSiO}_{2} / \mathrm{ZrO}_{2} \mathrm{SiO}_{2} / \alpha-\mathrm{Al}_{2} \mathrm{O}_{3}$ & Sol-gel & 20 & $\begin{array}{c}1-3 \mathrm{bar} \\
200{ }^{\circ} \mathrm{C}-500{ }^{\circ} \mathrm{C}\end{array}$ & $1.8 \times 10^{-7}$ & $480-730$ & {$[111]$} \\
\hline $\mathrm{ZrO}_{2} \mathrm{Y}_{2} \mathrm{OSiO}_{2} /$ ceramic & Sol-gel & - & $\begin{array}{c}1-1.5 \text { bar } \\
150{ }^{\circ} \mathrm{C}\end{array}$ & $1 \times 10^{-8}$ & 4 & {$[112]$} \\
\hline MTES-SiO $2 / \alpha-\mathrm{Al}_{2} \mathrm{O}_{3}{ }^{\text {b) }}$ & Sol-gel & - & $\begin{array}{c}1-6 \text { bar } \\
50{ }^{\circ} \mathrm{C}-200{ }^{\circ} \mathrm{C}\end{array}$ & $3.4 \times 10^{-9}$ & $24-46$ & {$[130]$} \\
\hline $\mathrm{SiO}_{2} / \gamma-\mathrm{Al}_{2} \mathrm{O}_{3} / \alpha-\mathrm{Al}_{2} \mathrm{O}_{3}$ & Sol-gel & $20-30$ & $\begin{array}{c}2 \text { bar } \\
600{ }^{\circ} \mathrm{C}\end{array}$ & $5 \times 10^{-7}$ & 5900 & {$[131]$} \\
\hline $\begin{array}{l}\mathrm{SiO}_{2} \text { modified/Vycor glass } \\
\text { (called Nanosil) }\end{array}$ & $\begin{array}{l}\text { High temperature } \\
\text { atmosphere } \mathrm{CVD}^{\mathrm{c})}\end{array}$ & - & $\begin{array}{c}1.2 \text { bar } \\
200{ }^{\circ} \mathrm{C}-700{ }^{\circ} \mathrm{C}\end{array}$ & $1.8 \times 10^{-8}$ & $23000-27000$ & {$[110]$} \\
\hline
\end{tabular}

a) $\mathrm{H}_{2} / \mathrm{CH}_{4}$ ideal selectivity; b) MTES: methyltriethoxysilane; c) CVD: chemical vapour deposition.

23000-27000 [110]. The drawback of silica membranes is its low resistance to water $[49,82]$. This challenge could be resolved by introducing metallic oxides such as oxides of cobalt [111] and zirconia [111,112] into the membrane fabrication stage as the metal ions may reduce the interactions between water-silica matrix and minimise the movement of silanol groups [111]. Certainly, due to the low content of water in natural gas $(<0.012 \%$ $(\mathrm{v} / \mathrm{v})[42,59])$, the impact of water on silica membranes in $\mathrm{H}_{2}$ separation from HENG is less significant than that in syngas industry, which contains up to $40 \%$ (v/v) $\mathrm{H}_{2} \mathrm{O}[15,30,39,41]$. To the best of our knowledge, investigation on the large scale $\mathrm{H}_{2} / \mathrm{CH}_{4}$ separation using silica membranes, especially from HENG streams, has been very limited. Thus, more investigations on mixed gas measurement and pilot scale study on $\mathrm{H}_{2} / \mathrm{CH}_{4}$ separation are needed to verify its performance in industry.

\subsubsection{Carbon molecular sieve (CMS) membranes}

CMS membranes have also been widely studied (Table 6) for $\mathrm{H}_{2}$ separation. The gas transport in CMS membranes mostly follows the molecular sieving mechanism. However, some large pores $(0.6-2 \mathrm{~nm}$ in diameter) could more preferably adsorb $\mathrm{CH}_{4}$ than $\mathrm{H}_{2}$ that leads to a reduction in $\mathrm{H}_{2}$ permeability and $\mathrm{H}_{2} / \mathrm{CH}_{4}$ selectivity $[49,113,114]$. Thus, it is critical to control the pore size in CMS membranes to be less than $0.6 \mathrm{~nm}$ in diameter. The CMS membranes is fabricated via the pyrolysis process of carbonaceous precursors $[49,50,115]$. The pore dimensions of CMS membranes can be controlled via the types of precursors, pyrolysis conditions and pre- and post-treatment processes [51,113]. It can be seen from Table 6 that the hydrogen permeance and $\mathrm{H}_{2} / \mathrm{CH}_{4}$ selectivity at ambient pressure may reach $10^{-7} \mathrm{~mol} \cdot \mathrm{m}^{-2} \cdot \mathrm{s}^{-1} \cdot \mathrm{Pa}^{-1}$ and 1200 , respectively. The CMS membranes were also proven to 
Table 6 A shortlist of carbon-based membranes for hydrogen separation

\begin{tabular}{|c|c|c|c|c|c|c|}
\hline Precursor & $\begin{array}{l}\text { Synthesis } \\
\text { method }\end{array}$ & $\begin{array}{c}\text { Thickness of active } \\
\text { layer/ } \mu \mathrm{m}\end{array}$ & $\begin{array}{l}\text { Experiment } \\
\text { conditions }\end{array}$ & $\begin{array}{l}\text { Hydrogen permeance } \\
/\left(\mathrm{mol} \cdot \mathrm{m}^{-2} \cdot \mathrm{s}^{-1} \cdot \mathrm{Pa}^{-1}\right)\end{array}$ & $\begin{array}{l}\text { Hydrogen } \\
\text { selectivity }\end{array}$ & Ref. \\
\hline 6FDA/BPDA-TMPDA ${ }^{\text {a) }}$ & Pyrolysis & $30-35$ & $\begin{array}{c}1-8.3 \text { bar } \\
25^{\circ} \mathrm{C}\end{array}$ & $3.4-7.5 \times 10^{-8}$ & $400-500^{b)}$ & [132] \\
\hline Kapton polyimide & Pyrolysis & $0.3-0.5$ & $\begin{array}{l}\text { Up to } 6 \text { bar } \\
30^{\circ} \mathrm{C}-2500^{\circ} \mathrm{C}\end{array}$ & $3.1 \times 10^{-10}$ & $150^{c)}$ & [133] \\
\hline $\begin{array}{l}\text { Phenol-formaldehyde } \\
\text { novolac resin }\end{array}$ & Pyrolysis & 45 & $\begin{array}{l}2 \mathrm{bar} \\
25{ }^{\circ} \mathrm{C}\end{array}$ & $1.7 \times 10^{-9}-1.2 \times 10^{-7}$ & $5-558^{b)}$ & [134] \\
\hline Polyimide & Pyrolysis & - & $\begin{array}{c}10.8 \mathrm{bar} \\
30^{\circ} \mathrm{C}-120^{\circ} \mathrm{C}\end{array}$ & $3.4 \times 10^{-7}-6.0 \times 10^{-8}$ & $132-631^{b)}$ & [135] \\
\hline Polyimide & Pyrolysis & - & $\begin{array}{l}10 \mathrm{bar} \\
80{ }^{\circ} \mathrm{C}\end{array}$ & $1.4 \times 10^{-7}$ & $540^{b)}$ & [136] \\
\hline Polypyrrolone & Pyrolysis & $40-50$ & $\begin{array}{l}1 \mathrm{bar} \\
35{ }^{\circ} \mathrm{C}\end{array}$ & $1.3-4.9 \times 10^{-8}$ & $270-1200^{b)}$ & [137] \\
\hline
\end{tabular}

a) 6FDA: 5,5-[2,2,2-trifluoro-1-(trifluoromethyl) ethylidene-1,3-isobenzofurandione; BPDA: 3,3',4,4'-biphenyl tetra carboxylic acid dianhydride; TMPDA: 2,4,6trimethyl-1,3-phenylenediamine; b) $\mathrm{H}_{2} / \mathrm{CH}_{4}$ mixed gas selectivity; c) $\mathrm{H}_{2} / \mathrm{N}_{2}$ ideal selectivity.

separate $\mathrm{H}_{2}$ effectively (e.g., achieving $98 \%$ recovery) from $50 \% \mathrm{H}_{2}-50 \% \mathrm{CH}_{4}(\mathrm{v} / \mathrm{v})$ mixed gas feeding condition [30]. The challenges for commercialising the CMS membranes are the membrane brittleness and high fabrication costs $[40,50]$ which require further improvement.

\subsubsection{Other inorganic microporous membranes}

Recently, two-dimensional nanomaterials have been integrated into membrane technology and showed the promising $\mathrm{H}_{2} / \mathrm{CH}_{4}$ separation performance. For instance, the study on graphene-based membranes, which could theoretically achieve single-atom thickness, showed high mechanical and chemical stability and high $\mathrm{H}_{2}$ separation performance (e.g., $1 \mathrm{~mol} \cdot \mathrm{m}^{-2} \cdot \mathrm{s}^{-1} \cdot \mathrm{Pa}^{-1} \mathrm{H}_{2}$ permeance and $10^{8} \mathrm{H}_{2} / \mathrm{CH}_{4}$ selectivity) [116]. The studies on hydrogen purification by layered double hydroxides (LDHs)-based membranes, which is formed by positively charged brucite-like layers and an interlayer region containing charge compensating molecules [117,118], also reached $10^{-7}-10^{-8} \mathrm{~mol} \cdot \mathrm{m}^{-2} \cdot \mathrm{s}^{-1} \cdot \mathrm{Pa}^{-1} \mathrm{H}_{2}$ permeance and $\sim 80 \mathrm{H}_{2} / \mathrm{CH}_{4}$ selectivity, respectively $[119,120]$. Although the two-dimensional membrane materials are a promising breakthrough in $\mathrm{H}_{2}$ separation, the major challenges for these membranes are to control the microstructures and to scale up the process [118].

\subsection{Metal organic framework (MOF) membranes}

Over recent decades, several studies focused on MOF membranes due to their ultrahigh porosity in comparison with other porous membranes [49,121,122], which enhances the gas sorption capacity and gas transport as a sequence. Some highlighted MOF membranes for hydrogen separation are summarised in Table 7, which indicates that $\mathrm{H}_{2}$ permeance in the MOF membranes is averagely 10 100 times higher than other porous membranes (e.g., $10^{-6}$ $\mathrm{mol} \cdot \mathrm{m}^{-2} \cdot \mathrm{s}^{-1} \cdot \mathrm{Pa}^{-1}$ versus $\left.10^{-7}-10^{-8} \mathrm{~mol} \cdot \mathrm{m}^{-2} \cdot \mathrm{s}^{-1} \cdot \mathrm{Pa}^{-1}\right)$. As organic linkers in MOF membranes cannot provide an additional linkage to surrounding MOF crystals and the membrane support, the major challenge is the fabrication of continuous and defect-free membranes $[49,122,123]$. This can be achieved via better pore shape and size control in the membrane fabrication process. For instance, Huang et al. fabricated a continuous defect-free ZIF-90 membrane on $\mathrm{Al}_{2} \mathrm{O}_{3}$ support by using 3-aminopropyltriethoxysilane as covalent linkers between ZIF-90 and $\mathrm{Al}_{2} \mathrm{O}_{3}$ support [122]. In a different approach, Liu et al. used the ZnAl-LDHs as a buffer for connecting the zeolitic-imidazolate framework-8 (ZIF-8) seed layer onto the $\mathrm{Al}_{2} \mathrm{O}_{3}$ support and the wellintergrown ZIF-8 membrane was formed during the secondary growth [120]. Recently, ZIF-8 is incorporated on hollow fibre membrane in a laboratory scale continuous process $[124,125]$, which shows a promising signal for commercial scale application of MOF membranes in the future.

\subsection{Polymeric membranes}

Polymeric membranes are the most mature membranes for hydrogen separation with the first industrial application reported in 1980s [42]. Some commercial membrane modules such as Prism ${ }^{\circledR}$ (Air products and Chemicals, Inc.) [142] and polyaramid module (Dupont) [143] could achieve up to $97 \%$ hydrogen recovery. The low costs, ease of fabricating a large area/volume ratio hollow fibre or spiral wound module makes polymeric membranes very competitive. Recently, polyimide-based membranes such as 6FDA and Matrimid ${ }^{\circledR}$ introduced on an industrial scale showed even better $\mathrm{H}_{2}$ transport than conventional polysulfone and cellulose acetate membranes $[42,50]$.

A critical limitation in polymer membrane performance is the trade-off between gas permeability and selectivity, also known as Robeson's upper bound (Fig. 4) [144,145]. However, the empirical upper bound relationship between 
Table 7 A shortlist of MOF membranes for hydrogen separation

\begin{tabular}{|c|c|c|c|c|c|c|}
\hline MOF type/support & Synthesis method & $\begin{array}{c}\text { Thickness of active } \\
\text { layer } / \mu \mathrm{m}\end{array}$ & $\begin{array}{l}\text { Experiment } \\
\text { conditions }\end{array}$ & $\begin{array}{l}\text { Hydrogen permeance } \\
/\left(\mathrm{mol} \cdot \mathrm{m}^{-2} \cdot \mathrm{s}^{-1} \cdot \mathrm{Pa}^{-1}\right)\end{array}$ & $\begin{array}{l}\text { Hydrogen } \\
\text { selectivity a) }\end{array}$ & Ref. \\
\hline$\overline{\mathrm{Cu}_{3}(\mathrm{BTC})_{2} / \mathrm{Cu} \text { net }}$ & Hydrothermal & 60 & $\begin{array}{l}1 \text { bar } \\
25^{\circ} \mathrm{C}\end{array}$ & $10^{-6}$ & 5.9 & {$[138]$} \\
\hline $\mathrm{ZIF}-90 / \alpha-\mathrm{Al}_{2} \mathrm{O}_{3}$ & Hydrothermal & 20 & $\begin{array}{c}1 \mathrm{bar} \\
25{ }^{\circ} \mathrm{C}-200{ }^{\circ} \mathrm{C}\end{array}$ & $\begin{array}{c}1.4 \times 10^{-7} \\
-2.5 \times 10^{-7}\end{array}$ & $7-16$ & {$[122]$} \\
\hline ZIF-8/Titania & $\begin{array}{c}\text { Hydrothermal and microwave } \\
\text { heating }\end{array}$ & $30-50$ & $\begin{array}{l}1.1-2 \mathrm{bar} \\
25^{\circ} \mathrm{C}\end{array}$ & $6 \times 10^{-8}$ & 11.2 & {$[139]$} \\
\hline $\begin{array}{l}\mathrm{ZIF}-8 / \mathrm{ZnAl}-\mathrm{NO}_{3} \\
\mathrm{LDHs} / \gamma-\mathrm{Al}_{2} \mathrm{O}_{3}\end{array}$ & Hydrothermal (in-situ growth) & 1.3 & $\begin{array}{l}1 \text { bar } \\
25^{\circ} \mathrm{C}\end{array}$ & $1.4 \times 10^{-7}$ & 12.5 & {$[119]$} \\
\hline $\mathrm{ZIF}-95 / \alpha-\mathrm{Al}_{2} \mathrm{O}_{3}$ & Hydrothermal (in-situ growth) & 30 & $\begin{array}{c}1 \mathrm{bar} \\
325^{\circ} \mathrm{C}\end{array}$ & $1.9 \times 10^{-6}$ & 11.0 & {$[140]$} \\
\hline Ni-MOF-74 & Hydrothermal (in-situ growth) & $10-25$ & $\begin{array}{l}1 \mathrm{bar} \\
25^{\circ} \mathrm{C}\end{array}$ & $10^{-6}$ & 2.9 & {$[141]$} \\
\hline $\begin{array}{l}\mathrm{NH}_{2}-\mathrm{MIL}-53(\mathrm{Al}) \\
\text { /Glass frit }\end{array}$ & $\begin{array}{l}\text { Colloidal assembly of } \\
\text { MOF seeds }\end{array}$ & 15 & $\begin{array}{c}1 \mathrm{bar} \\
15^{\circ} \mathrm{C}-80{ }^{\circ} \mathrm{C}\end{array}$ & $1.5 \times 10^{-6}$ & 20.7 & {$[123]$} \\
\hline
\end{tabular}

a) $\mathrm{H}_{2} / \mathrm{CH}_{4}$ mixed gas selectivity.

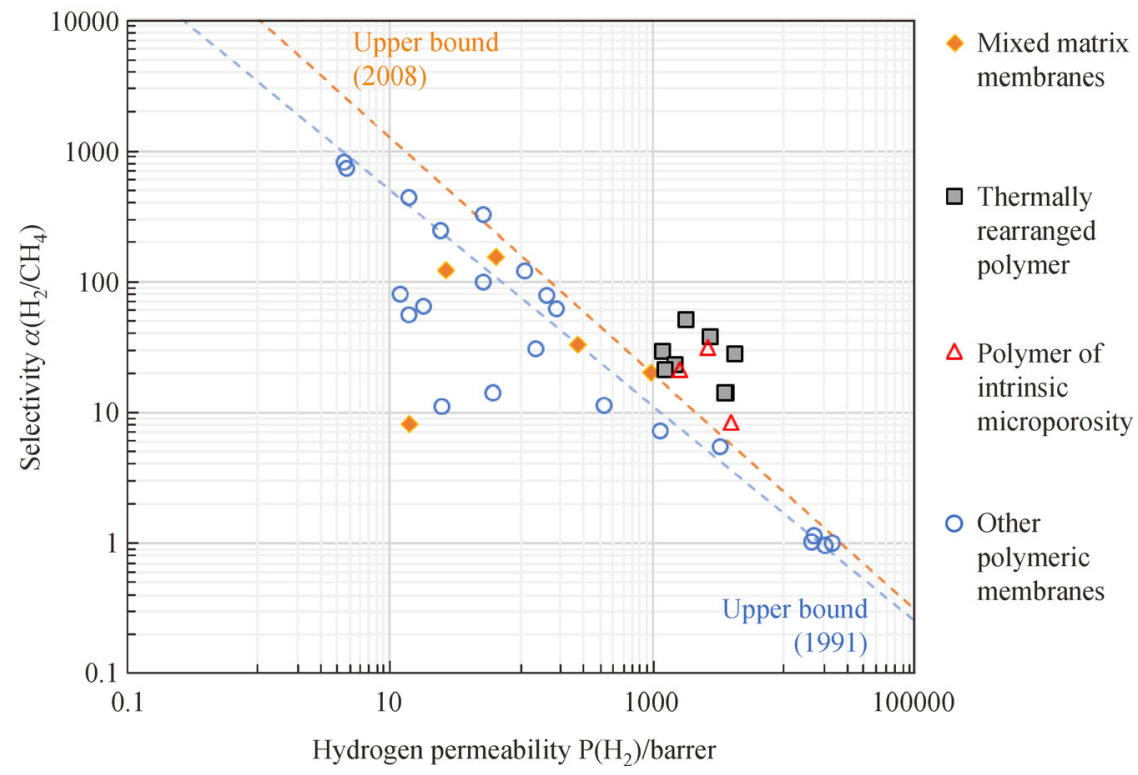

Fig. 4 Robeson's upper bound for $\mathrm{H}_{2} / \mathrm{CH}_{4}$ separation of polymeric membranes. Data from [142,144,145,149-157]. Updated based on Ref. [159], with permission. Copyright 2020, Chinese Academy of Engineering and Higher Education Press.

$\mathrm{H}_{2}$ permeability and $\mathrm{H}_{2} / \mathrm{CH}_{4}$ selectivity is a temporary figure that will be shifted to the higher limit with more advanced membrane structures and properties discovered $[144,145]$. In fact, several approaches have been investigated to crossover the upper bound. In last decades, many laboratory scale membranes have been reported to cross the upper bound such as polymer of intrinsic microporosity (PIM) membrane [146-148] and thermally rearranged (TR) polymer membranes [149-153]. The incorporation of CMS [154], ZIF [155,156], UiO-66 [156] and multiwalled carbon nanotube [157] into polymeric membranes, which is called mixed matrix membrane (MMM), also demonstrated the potential to enhance the $\mathrm{H}_{2}$ permeability without reducing or even increasing the
$\mathrm{H}_{2} / \mathrm{CH}_{4}$ selectivity. Simultaneously, researchers have fabricated the defect-free ultra-thin polymeric membranes $(\sim 30 \mathrm{~nm})$ by continuously assembly of polymer (CAP) technique [158] that showed a breakthrough in gas permeance. Certainly, most of the advanced $\mathrm{H}_{2}$ selective membranes and fabrication techniques are on laboratory scales that require more investigations and efforts to convert them into industry.

2.7 Impact of minor impurities in natural gas grid on membrane performance

The typical gas standard regulations in many areas still allow the presence of minor impurities such as $\mathrm{CO}_{2}, \mathrm{H}_{2} \mathrm{~S}$, 
water, $\mathrm{C}_{3+}$ hydrocarbons and inert gases in the natural gas pipeline grids $[59,160]$. Organosulfur compounds such as dimethyl sulphide and tetrahydrothiophene are also injected into the commercial natural gas stream at concentrations around $0.00002 \%(\mathrm{v} / \mathrm{v})$ as a legislative practice for detecting natural gas leakage $[161,162]$. These compounds are commonly removed via the hydrodesulfurization process prior to entering the methane reforming reactors [163]. However, such desulfurization process requires high energy inputs to maintain high reaction pressure and temperature [30]. Hence, an essential factor in selecting the membrane materials for hydrogen recovery from HENG is to consider their resistance to potential minor impurities in natural gas. Generally, the presence of these impurities could alter the membrane performance by following four ways: 1) competing with hydrogen to permeate through the membrane; 2) occupying and blocking the membrane free volume; 3) plasticising the membrane; 4) degrading or poisoning the membrane materials [41].

\subsubsection{Dense metallic membranes}

Due to the special hydrogen transport mechanism, hydrogen permeation through dense metallic membranes is not affected by most of impurities except $\mathrm{H}_{2} \mathrm{~S}$. It was reported that $\mathrm{H}_{2} \mathrm{~S}$ at concentrations $\sim 0.0002 \%(\mathrm{v} / \mathrm{v})$ can react with conventional $\mathrm{Pd}$ and $\mathrm{Pt}$ membranes to form the metal sulphide on the membrane surface, which then completely inhibit the $\mathrm{H}_{2}$ permeation through the membrane $[63,164,165]$. Such limitation can be minimised by fabricating the $\mathrm{Pd}$ alloy membranes with metals in group IB, IVB, VB and VIB of the periodic table. Peters et al. [164] observed only 20\%-30\% loss in $\mathrm{H}_{2}$ flux when exposing a $\mathrm{Pd}_{77} \mathrm{Ag}_{23}$ membrane (thickness $10 \mu \mathrm{m}$ ) to $5 \times$ $10^{-7}-0.002 \%(\mathrm{v} / \mathrm{v}) \mathrm{H}_{2} \mathrm{~S} / \mathrm{H}_{2}$ mixed gas for $265 \mathrm{~h}$. Recent studies further demonstrated that the close to full recovery of $\mathrm{H}_{2}$ flux through $\mathrm{Pd}$ alloy membranes were obtained when removing the $\mathrm{H}_{2} \mathrm{~S}$ in the feed gas [164,165]. This suggested that the dominant interaction of $\mathrm{H}_{2} \mathrm{~S}$ and alloy membranes was reversible adsorption rather than sulfidation reaction.

\subsubsection{Molecular sieve membranes}

Figure 5 showed that the kinetic diameter of $\mathrm{H}_{2}$ is much smaller than most of potential impurities. Thus, these impurities retain in the retentate side of the molecular sieving mechanism driving membranes, along with $\mathrm{CH}_{4}$. Figure 5 also showed that $\mathrm{H}_{2} \mathrm{O}$ is more permeable than $\mathrm{H}_{2}$ that could reduce the purity of hydrogen product stream. $\mathrm{H}_{2} \mathrm{O}$ was also reported to densify the silica membrane at temperature above $500{ }^{\circ} \mathrm{C}[88,166]$. However, the impact of $\mathrm{H}_{2} \mathrm{O}$ on the purity of $\mathrm{H}_{2}$ product stream is often negligible due to the strict control of $\mathrm{H}_{2} \mathrm{O}$ content in natural gas grids (e.g., commonly in $10^{-7}-10^{-4} \%(\mathrm{v} / \mathrm{v})$ level $[59,160])$ to avoid the formation of hydrates. The water-resistance of silica membrane could also be overcome by doping the metal oxides into silica matrix $[166,167]$ or replacing hydroxyl functional group $(-\mathrm{OH})$ on the pore surfaces by methyl $\left(-\mathrm{CH}_{3}\right)$ [168] or perfluorodecyl functional groups [169].

In addition, impurities with high condensation temperature such as $\mathrm{C}_{3+}$ hydrocarbon, sulfur compounds and water on microporous membranes may condense and block the membrane pores, which can potentially reduce the hydrogen permeability but enhance the $\mathrm{H}_{2} / \mathrm{CH}_{4}$ selectivity [88,170-172].

\subsubsection{Dense polymeric membranes}

The effects of impurities on hydrogen separation depend on their solubility and diffusivity in the materials for those membranes relying on solution-diffusion gas transport mechanism. In comparison with $\mathrm{H}_{2}$, most impurities have larger kinetic diameter (lower gas diffusivity) and higher condensation temperature (higher gas solubility) (Fig. 5). As the preferred membrane materials (Section 2.6) for $\mathrm{H}_{2}$ recovery from HENG are mostly relying on diffusivity selection such as glassy polymer (e.g., cellulose acetate
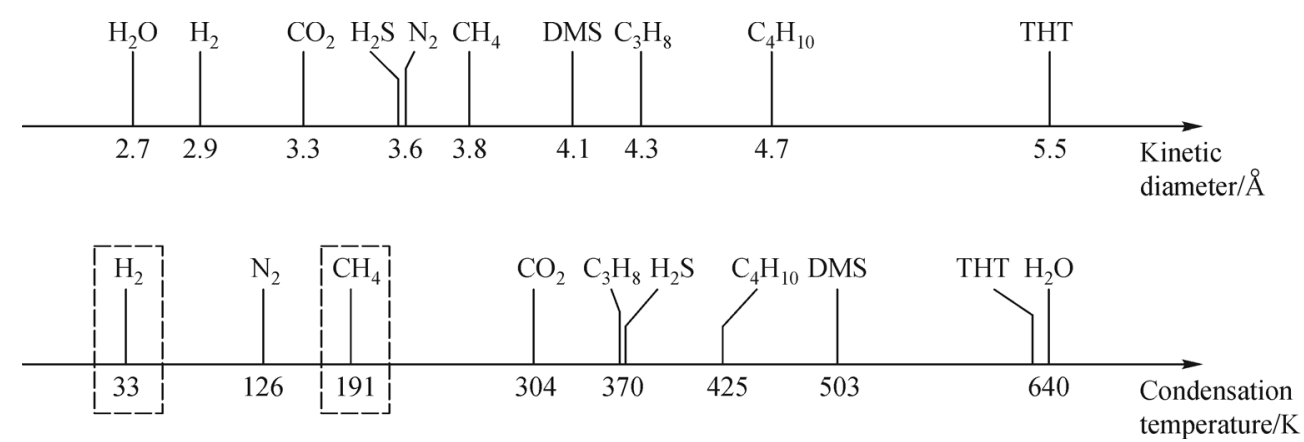

Fig. 5 The kinetic diameter and critical temperature of some potential components in natural gas [59,173] (data for dimethyl sulphide and tetrahydrothiophene obtained from [174] and conductor like screening model, respectively). Updated based on Ref. [59], with permission. Copyright 2008, American Chemical Society. 
[173] and polysulfone [51]), impurities with high condensation temperature may condense and block the membrane free volume. Schell et al. [172] reported that the presence of $0.12 \%(\mathrm{v} / \mathrm{v})$ water vapour $\left(80 / 20(\mathrm{v} / \mathrm{v}) \mathrm{H}_{2} /\right.$ $\mathrm{CH}_{4}$ feed gas at $60^{\circ} \mathrm{C}$ and $2410 \mathrm{kPa}$ ) supressed the $\mathrm{H}_{2}$ flux through cellulose acetate membranes by $6 \%$ and enhanced the $\mathrm{H}_{2} / \mathrm{CH}_{4}$ selectivity by $4 \%$. The researchers also observed the similar phenomenon (i.e., $15 \%$ decrease in $\mathrm{H}_{2}$ flux and $10 \%$ increase in $\mathrm{H}_{2} / \mathrm{CH}_{4}$ selectivity) when introducing aromatic hydrocarbons into $\mathrm{H}_{2} / \mathrm{CH}_{4}$ mixed gas.

The condensates inside the membrane may also plasticise the membrane matrix and lead to an increase in permeation of all penetrants and decrease in gas selectivity [59]. However, most studies have shown that polymeric membranes have strong resistance to impurities such as $\mathrm{H}_{2} \mathrm{~S}, \mathrm{C}_{3+}$, etc. in crude natural gas $[51,172,173]$, which is beneficial for the $\mathrm{H}_{2}$ separation from HENG. Nevertheless, the impacts of impurities in commercial natural gas, specially added odorants, on this membrane materials are not yet clear and need further investigation.

\section{Discussion and outlook}

\subsection{Discussion}

Overall, the pathway of converting $\mathrm{P} 2 \mathrm{H}$ is a prospective solution for storing and redistributing surplus renewable energy to ensure a clean, secure and sustainable energy supply future. Recent techno-economic analysis estimated that the bulk energy storage cost (USD per kW) of $\mathrm{P} 2 \mathrm{H}$ technology can be 1.5-4.3 times less than other energy storage technologies such as batteries, supercapacitors, pumped hydro and flywheels [175]. Although the delivery and temporary storage of hydrogen in natural gas pipelines inherit the advantages of the existing natural gas distribution network, efficient and cost-effective technologies that purifies hydrogen from HENG is the key to push $\mathrm{P} 2 \mathrm{H}$ into practice. Hydrogen separation has been well investigated in syngas and methane reformed off gas industries $[15,30,39,40]$, however, very few studies were conducted for $\mathrm{H}_{2}$ separation from HENG.

The hydrogen separation performance of different membrane materials has been discussed and summarised in Table 8 and Fig. 6. Although dense metallic membranes are promising to achieve an extremely high hydrogen purity and comparative hydrogen permeance or recovery in comparison with other membrane materials, the high operating temperature $\left(\geqslant 300^{\circ} \mathrm{C}\right)$ hinders its application in hydrogen recovery from HENG. Ceramic mixed protonicelectronic conducting membranes are not suitable for hydrogen purification from HENG due to high operating temperature $\left(\geqslant 400{ }^{\circ} \mathrm{C}\right)$ requirement and the ability to dimerising $\mathrm{CH}_{4}$. Polymeric membranes are leading in the commercially readiness compared to other hydrogen separation membranes with only low operating temperature required. The challenges for these membranes are the moderate $\mathrm{H}_{2}$ selectivity which limits the hydrogen purity in product stream. In addition, inorganic microporous and metal organic framework membranes are also promising for hydrogen separation at low operating temperatures such as ambient temperature. The key to these membranes is to improve the reproductivity in membrane fabrication and performance, especially on pilot- and industrial-scale.

\subsection{Research and development (R\&D) outlook}

Many promising membrane materials for hydrogen recovery from HENG, including their fabrications and separation performance, have been highlighted and discussed. On this basis, we would like to address the $\mathrm{R} \& \mathrm{D}$ outlook to achieve the high hydrogen purification membranes and drive membrane separation into HENG industry.

3.2.1 Development of novel membrane materials and membrane fabrication technologies

To the greatest extent, the development of hydrogen purification membranes will remain focusing on the following key approaches: 1) design and synthesis of novel membrane materials with high $\mathrm{H}_{2} / \mathrm{CH}_{4}$ selectivity and permeability; 2) modification of the structure and morphology of existing membranes; 3 ) incorporation of different membranes into a copolymer, composite or MMM to combine the best features of each membrane material; 4) development of advanced membrane fabrication technologies to produce ultrathin membranes.

The gas transport mechanisms for $\mathrm{H}_{2} / \mathrm{CH}_{4}$ separation membranes are dominant by molecular sieving and solution-diffusion (with diffusion selectivity). Both mechanisms require the well control of membrane morphology such as pore sizes and shapes, fractional free volume distribution etc., to enhance $\mathrm{H}_{2} / \mathrm{CH}_{4}$ selectivity. Thus, the $\mathrm{R} \& \mathrm{D}$ is expected to shift towards membrane materials that either have uniform pore size such as MOF and two-dimensional membranes (i.e., graphene-based membranes, LDHs membranes, etc.) or the ability to tune or crosslink the membrane free volume such as TR polymers and PIMs membranes. Simultaneously, the incorporation of advanced membrane materials with commercialised membrane materials will also attract great interests. The incorporation could combine the best features of each membrane material and overcome current challenges in fabricating large defect-free membranes. The commercial readiness of conventional membranes could also potentially reduce the time consumption for scaling up the incorporated membranes.

Another crucial approach for enhancing the hydrogen 
recovery is to reduce the thickness of active membrane layer but maintain its selectivity and mechanical strength. Along with the conventional thin film composite membranes, the ultra-thin film coating techniques such as CAP and metal-induced ordered microporous polymer thin film composite membranes are able to reduce the membrane thickness to nanometre scale without affecting the gas selectivity. Therefore, it is worthwhile to drive the R\&D in $\mathrm{H}_{2}$ selective membrane fabrication towards this field, starting with investigations on precursor selection for CAP processes of advanced membrane materials.

\subsubsection{Pilot scale and economic assessment studies}

The development of membrane technologies in hydrogen purification has been relying on conventional polymeric membrane materials and palladium membranes (Table 8). Although several membrane materials have been introduced for $\mathrm{H}_{2} / \mathrm{CH}_{4}$ separation, there are very few membrane modules introduced into practice such as Vaporsep- $\mathrm{H}_{2}{ }^{\mathrm{TM}}$ solution developed by Membrane Technology and Research (USA) [177] and Micro-Channel ${ }^{\mathrm{TM}}$ Technology developed by Power and Energy Inc. (USA) [81]. Beside the lack of technology to support the fabrication of large defect-free membranes as addressed above, the lack of pilot scale studies is another major obstacle for commercialising advanced membrane materials. Therefore, more investigations on pilot-scale membranes studies are recommended.

The cost of $\mathrm{H}_{2}$ separation from $10 / 90(\mathrm{v} / \mathrm{v}) \mathrm{H}_{2} / \mathrm{CH}_{4}$ at 20 bar and $80 \%$ recovery was estimated to be $3.3-8.3$ USD $\cdot \mathrm{kg}^{-1} \mathrm{H}_{2}$ using the PSA [30]. The target of $\mathrm{H}_{2}$ cost is proposed to be $1.5 \mathrm{USD} \cdot \mathrm{kg}^{-1} \mathrm{H}_{2}$ [84]. However, there is lack of techno-economic study on hydrogen recovery from HENG using membrane technologies. Data collected from pilot scale studies will also be valuable for economic assessments and further upscale of these membranes.

The majority of laboratory studies on hydrogen purification membranes focused on pure $\mathrm{H}_{2}$ and $\mathrm{CH}_{4}$ separation performance at low operating pressures and a few on $\mathrm{H}_{2} / \mathrm{CH}_{4}$ mixtures. In the real world, membranes for hydrogen recovery from HENG may expose to several impurities (section 2.7) and high pressures (68 bar and ambient temperature). Thus, it is worthwhile to investigate the performance of candidate membranes in real HENG conditions, particularly for pilot studies.

\subsubsection{Membrane modelling}

The transition of technology from laboratory to industry requires extraordinary efforts and resources, especially for membranes in the new $\mathrm{P} 2 \mathrm{H}$ energy sector. Hence, developing robust membrane models validated with experiments is essential to minimise the $R \& D$ costs and accelerate the technology transition. Several mathematical models have been developed for $\mathrm{CO}_{2} / \mathrm{H}_{2}$ separation in integrated gasification combined cycle process [178-181]. By counting that $\mathrm{CH}_{4}$ behaving more inert than $\mathrm{CO}_{2}$ in membrane separation [57], these models will be the valuable resources for the process development of hydrogen purification from HENG.

\subsubsection{Technology integration}

While membrane technology has advantages of cost effectiveness and small facility footprint, purify $\mathrm{H}_{2}$ stream up to $99.99 \%(\mathrm{v} / \mathrm{v})$ from HENG at low temperatures is a critical challenge. Another technology that can achieve 99.99\% (v/v) $\mathrm{H}_{2}$ purity is the PSA, which is a mature technology for hydrogen separation [182]. However, PSA requires large land footprint to accommodate the adsorption and frequent regeneration cycles for hydrogen separation from its low concentration mixtures [50]. Therefore, an integrated membrane-adsorption process (Fig. 7) is a promising approach to combine the best of both technologies $[23,159,183]$. Recently, Liemberger et al. reported an integrated process of an aromatic polyimide hollow fibre membrane module with a PSA that could recover at least $60 \% \mathrm{H}_{2}$ at purity $98.0 \%-99.3 \%(\mathrm{v} / \mathrm{v})$ from 1/99-10/90 (v/v) $\mathrm{H}_{2} / \mathrm{CH}_{4}$ feed gas at $21-51$ bar and

Table 8 Summary of hydrogen separation performance of some common membrane materials $[40,49-51,88,159,176]$

\begin{tabular}{|c|c|c|c|c|c|c|c|}
\hline \multirow{2}{*}{ Item } & \multirow{2}{*}{$\begin{array}{l}\text { Dense metallic } \\
\text { membranes }\end{array}$} & \multirow{2}{*}{$\begin{array}{c}\text { Ceramic mixed } \\
\text { protonic-electronic } \\
\text { conducting membranes }\end{array}$} & \multicolumn{3}{|c|}{ Inorganic microporous membranes ${ }^{\text {a) }}$} & \multirow{2}{*}{$\begin{array}{c}\text { MOF } \\
\text { membranes }\end{array}$} & \multirow{2}{*}{$\begin{array}{l}\text { Polymeric } \\
\text { membranes }\end{array}$} \\
\hline & & & Zeolite & Silica & Carbon based & & \\
\hline Temperature $/{ }^{\circ} \mathrm{C}$ & $300-600$ & $400-1000$ & $25-700$ & $50-700$ & $25-900$ & $15-325$ & $25-200$ \\
\hline $\mathrm{H}_{2} / \mathrm{CH}_{4}$ selectivity & $1000-\infty^{b)}$ & $-{ }^{c)}$ & $4-25^{\text {d) }}$ & Up to $5900^{\text {e) }}$ & Up to 1200 & $3-21$ & Up to 730 \\
\hline $\begin{array}{l}\text { Hydrogen permeance } \\
/\left(\mathrm{mol} \cdot \mathrm{m}^{-2} \cdot \mathrm{s}^{-1} \cdot \mathrm{Pa}^{-1}\right)\end{array}$ & $\begin{array}{l}2 \times 10^{-7} \\
-4 \times 10^{-6}\end{array}$ & $10^{-8}-10^{-9}$ & $\begin{array}{c}2 \times 10^{-8} \\
-8 \times 10^{-7}\end{array}$ & $\begin{array}{c}3 \times 10^{-9} \\
-5 \times 10^{-7}\end{array}$ & $\begin{array}{c}2 \times 10^{-9} \\
-3 \times 10^{-7}\end{array}$ & $\begin{array}{c}6 \times 10^{-8} \\
-2 \times 10^{-6}\end{array}$ & $\begin{array}{c}\sim 10^{-9} \\
-3 \times 10^{-7}\end{array}$ \\
\hline Development stage & $\begin{array}{c}\text { Small } \\
\text { commercial } \\
\text { scale }\end{array}$ & $\begin{array}{c}\text { Lab-scale } \\
\text { membrane } \\
\text { modules }\end{array}$ & $\begin{array}{c}\text { Lab-scale } \\
\text { membrane } \\
\text { modules }\end{array}$ & $\begin{array}{c}\text { Lab-scale } \\
\text { membrane } \\
\text { modules }\end{array}$ & $\begin{array}{c}\text { Lab-scale } \\
\text { membrane } \\
\text { modules }\end{array}$ & $\begin{array}{c}\text { Lab-scale } \\
\text { membrane } \\
\text { modules }\end{array}$ & $\begin{array}{c}\text { Large } \\
\text { commercial } \\
\text { scale }\end{array}$ \\
\hline
\end{tabular}

a) The summary excludes some advanced membrane materials that require more database to make the conclusion; b) $\mathrm{H}_{2} / \mathrm{N}_{2}$ selectivity with assumption that selectivity of $\mathrm{H}_{2} / \mathrm{N}_{2}$ and $\mathrm{H}_{2} / \mathrm{CH}_{4}$ being identical [57]; c) the selectivity of $\mathrm{H}_{2}$ in ceramic mixed protonic-electronic conducting membrane is proposed to similar to dense metallic membrane. However, there is limited data reported in literature [88]; d) MFI type zeolite membrane prepared by catalyst cracking deposition hydrothermal synthesis could achieve up to $180 \mathrm{H}_{2} / \mathrm{CH}_{4}$ selectivity [108]; e) nanosil membrane could achieve 23000-27000 $\mathrm{H}_{2} / \mathrm{CH}_{4} \mathrm{Selectivity} \mathrm{[110]}^{2}$ 


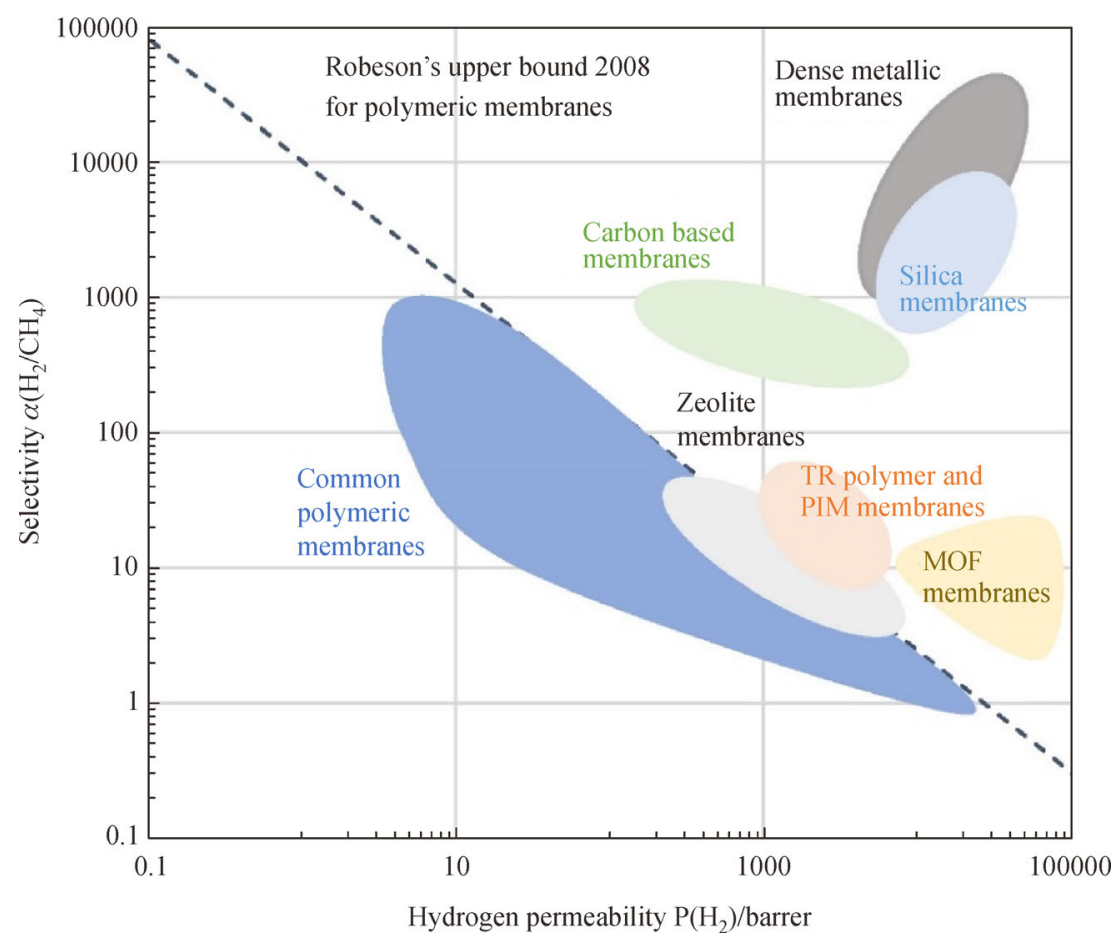

Fig. 6 Summary of $\mathrm{H}_{2}$ permeability versus $\mathrm{H}_{2} / \mathrm{CH}_{4}$ selectivity of some common membrane materials based on the literature data summarised in this review. Since the membrane thickness were not fully reported in literature, the $\mathrm{H}_{2}$ permeation is presented in term of $\mathrm{H}_{2}$ permeability instead of permeance. $\left(\alpha\left(\mathrm{H}_{2} / \mathrm{CH}_{4}\right)\right.$ selectivity in dense metallic membranes was based on $\mathrm{H}_{2} / \mathrm{N}_{2}$ selectivity by assuming the identical performance of $\mathrm{N}_{2}$ and $\mathrm{CH}_{4}$ through the membrane [57]).

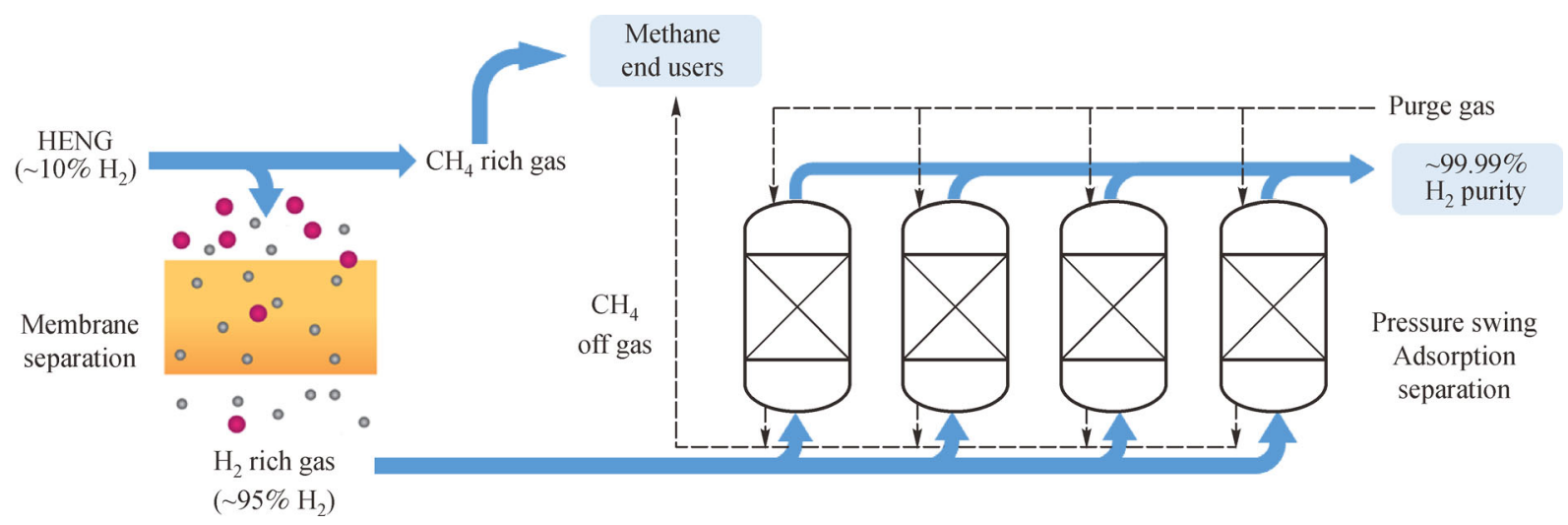

Fig. 7 The integrated module of membrane-adsorption process for hydrogen purification [159]. Adapted with permission from Ref. [159]. Copyright 2020, Chinese Academy of Engineering and Higher Education Press.

ambient temperature [23]. Certainly, the technology integration opportunity will also be open to other hydrogen purification technologies such as cryogenic and solvent absorption. Hence, more investigations on the integrated hydrogen separation units such as material development, process optimisation and economic analysis are suggested to testify its industry potential.

Acknowledgements The authors acknowledge the support of Early Career Researcher Grants Scheme awarded by the University of Melbourne entitled 'Production of High Purity Hydrogen from Mixed Pipeline Gases' and Future
Fuel Cooperative Research Centre (CRC) 'Novel Separation Technology development for hydrogen and future fuels systems'.

\section{References}

1. BP. BP Energy Outlook: 2019 edition. 2019

2. International Energy Agency. World Energy Outlook 2013. Flagship report. 2013

3. International Energy Agency. Oil 2020. Fuel Report. 2020

4. United Nations. Paris Agreement-United Nations Framework 
Convention on Climate Change. 2015

5. Pour N, Webley P A, Cook P J. Opportunities for application of BECCS in the Australian power sector. Applied Energy, 2018, 224 : 615-635

6. Kemper J. Biomass and carbon dioxide capture and storage: a review. International Journal of Greenhouse Gas Control, 2015, 40: 401-430

7. Rubin E, Meyer L, Coninck H D, Abanades J C, Akai M, Benson S, Caldeira K, Cook P, Davidson O, Doctor R, et al. IPCC special report on carbon dioxide capture and storage. Carbon Dioxide Capture and Storage. 2005

8. Global CCS Institute. The Global Status of CCS. 2017

9. Andrews J, Shabani B. Re-envisioning the role of hydrogen in a sustainable energy economy. International Journal of Hydrogen Energy, 2012, 37(2): 1184-1203

10. Mohn K. The gravity of status quo: a review of IEA's world energy outlook. Economics of Energy \& Environmental Policy, 2020, 9 (1), DOI: $10.5547 / 2160-5890.8 .2 . \mathrm{kmoh}$

11. International Energy Agency. Market Report Series: Renewables 2018: Analysis and Forecasts to 2023. 2018

12. Pecher A, Kofoed J P. Handbook of Ocean Wave Energy. London: Springer Nature, 2017, 20

13. International Energy Agency. Global Energy \& $\mathrm{CO}_{2}$ Status Report 2019. Flagship Report. 2019

14. Robinius M, Raje T, Nykamp S, Rott T, Müller M, Grube T, Katzenbach B, Küppers S, Stolten D. Power-to-gas: electrolyzers as an alternative to network expansion - an example from a distribution system operator. Applied Energy, 2018, 210: 182197

15. Maroufmashat A, Fowler M. Transition of future energy system infrastructure through power-to-gas pathways. Energies, 2017, 10 (8): 1089

16. Kreuter W, Hofmann H. Electrolysis: the important energy transformer in a world of sustainable energy. International Journal of Hydrogen Energy, 1998, 23(8): 661-666

17. Ursua A, Gandia L M, Sanchis P. Hydrogen production from water electrolysis: current status and future trends. Proceedings of the IEEE, 2011, 100(2): 410-426

18. Laguna Bercero M. Recent advances in high temperature electrolysis using solid oxide fuel cells: a review. Journal of Power Sources, 2012, 203: 4-16

19. Götz M, Lefebvre J, Mörs F, McDaniel Koch A, Graf F, Bajohr S, Reimert R, Kolb T. Renewable power-to-gas: a technological and economic review. Renewable Energy, 2016, 85: 1371-1390

20. Ehteshami S M M, Chan S H. The role of hydrogen and fuel cells to store renewable energy in the future energy network - potentials and challenges. Energy Policy, 2014, 73: 103-109

21. International Energy Agency. The Future of Hydrogen. Technology Report. 2019

22. Sato S, Nagai K. Polymer membranes with hydrogen-selective and hydrogen-rejective properties. Membrane, 2005, 30(1): 20-28

23. Liemberger W, Groß M, Miltner M, Harasek M. Experimental analysis of membrane and pressure swing adsorption (PSA) for the hydrogen separation from natural gas. Journal of Cleaner Production, 2017, 167: 896-907

24. Gahleitner G. Hydrogen from renewable electricity: an interna- tional review of power-to-gas pilot plants for stationary applications. International Journal of Hydrogen Energy, 2013, 38(5): 2039-2061

25. Sinigaglia T, Lewiski F, Santos Martins M E, Mairesse Siluk J C. Production, storage, fuel stations of hydrogen and its utilization in automotive applications: a review. International Journal of Hydrogen Energy, 2017, 42(39): 24597-24611

26. Demir M E, Dincer I. Cost assessment and evaluation of various hydrogen delivery scenarios. International Journal of Hydrogen Energy, 2018, 43(22): 10420-10430

27. Saadi F H, Lewis N S, McFarland E W. Relative costs of transporting electrical and chemical energy. Energy \& Environmental Science, 2018, 11(3): 469-475

28. van der Zwaan B C C, Schoots K, Rivera Tinoco R, Verbong G P J. The cost of pipelining climate change mitigation: an overview of the economics of $\mathrm{CH}_{4}, \mathrm{CO}_{2}$ and $\mathrm{H}_{2}$ transportation. Applied Energy, 2011, 88(11): 3821-3831

29. Dodds P E, Staffell I, Hawkes A D, Li F, Grünewald P, McDowall W, Ekins P. Hydrogen and fuel cell technologies for heating: a review. International Journal of Hydrogen Energy, 2015, 40(5): 2065-2083

30. Melaina $\mathrm{M} \mathrm{W}$, Antonia O, Penev M. Blending Hydrogen into Natural Gas Pipeline Networks. A Review of Key Issues. Technical Report NREL/TP-5600-51995. 2013

31. SNAM. Global Gas Report 2018. Washington D.C.: International Gas Union, 2018

32. Yang C, Ogden J. Determining the lowest-cost hydrogen delivery mode. International Journal of Hydrogen Energy, 2007, 32(2): 268-286

33. Schmura E, Klingenberg M, Paster M, Gruber J. Existing Natural Gas Pipeline Materials and Associated Operational Characteristics. DOE Hydrogen Program-FY 2005 Progress Report. 2005

34. Al Rafea K. Utilizing 'power-to-gas' technology for storing energy and to optimize the synergy between environmental obligations and economical requirements. Dissertation for the Doctoral Degree. Ontario: University of Waterloo, 2017, 13

35. Altfeld K, Pinchbeck D. Admissible hydrogen concentrations in natural gas systems. Gas Energy, 2013, 2103(03): 1-2

36. Penev M, Melaina M, Bush B, Muratori M, Warner E, Chen Y. Low-Carbon Natural Gas for Transportation: Well-to-Wheels Emissions and Potential Market Assessment in California. Technical Report NREL/TP-6A50-66538. 2016

37. Jemena Gas Networks (NSW) Limited. Western Sydney Green Gas Project-Environmental Impact Statement. 2019

38. Karim G A, Wierzba I, Al Alousi Y. Methane-hydrogen mixtures as fuels. International Journal of Hydrogen Energy, 1996, 21(7): 625-631

39. Todd D M. Gas turbine improvements enhance IGCC viability. In: Proceedings of the 2000 Gasification Technologies Conference. Schenectady, NY: GE Power Systems, 2000, 8-11

40. Adhikari S, Fernando S. Hydrogen membrane separation techniques. Industrial \& Engineering Chemistry Research, 2006, 45(3): 875-881

41. Lu H T. The impact of impurities on the performance of cellulose triacetate membranes for $\mathrm{CO}_{2}$ separation. Dissertation for the Doctoral Degree. Parkville: The University of Melbourne, 2018, 
$3-47$

42. Baker R W. Future directions of membrane gas separation technology. Industrial \& Engineering Chemistry Research, 2002, 41(6): 1393-1411

43. Ghosal K, Freeman B D. Gas separation using polymer membranes: an overview. Polymers for Advanced Technologies, 1994, 5(11): 673-697

44. Merkel T C, Lin H, Wei X, Baker R. Power plant post-combustion carbon dioxide capture: an opportunity for membranes. Journal of Membrane Science, 2010, 359(1-2): 126-139

45. Kentish S E, Scholes C A, Stevens G W. Carbon dioxide separation through polymeric membrane systems for flue gas applications. Recent Patents on Chemical Engineering, 2008, 1(1): 52-66

46. Chen G, Buck F, Kistner I, Widenmeyer M, Schiestel T, Schulz A, Walker M, Weidenkaff A. A novel plasma-assisted hollow fiber membrane concept for efficiently separating oxygen from $\mathrm{CO}$ in a $\mathrm{CO}_{2}$ plasma. Chemical Engineering Journal, 2020, 392: 123699

47. Bogaerts A, Neyts E C. Plasma technology: an emerging technology for energy storage. ACS Energy Letters, 2018, 3(4): 1013-1027

48. Barelli L, Bidini G, Gallorini F, Servili S. Hydrogen production through sorption-enhanced steam methane reforming and membrane technology: a review. Energy, 2008, 33(4): 554-570

49. Li P, Wang Z, Qiao Z, Liu Y, Cao X, Li W, Wang J, Wang S. Recent developments in membranes for efficient hydrogen purification. Journal of Membrane Science, 2015, 495: 130-168

50. Zornoza B, Casado C, Navajas A. Chapter 11 Advances in Hydrogen Separation and Purification with Membrane Technology. Amsterdam: Elsevier, 2013, 245-268

51. Ockwig N W, Nenoff T M. Membranes for hydrogen separation. Chemical Reviews, 2007, 107(10): 4078-4110

52. Koros W J, Fleming G. Membrane-based gas separation. Journal of Membrane Science, 1993, 83(1): 1-80

53. Hu G, Jiang K, Wang R, Li G. Chapter 7. Technological assessment of $\mathrm{CO}_{2}$ capture and EOR/EGR/ECBM-based storage. In Cheung $\mathrm{F}$ M, Hong $\mathrm{Y}$, eds. Green Finance, Sustainable Development, and the Belt and Road Initiative. London: Taylor \& Francis, 2021, ISBN: 9780367898809

54. Uhlhorn R, Keizer K, Burggraaf A. Gas and surface diffusion in modified $\gamma$-alumina systems. Journal of Membrane Science, 1989, 46(2-3): 225-241

55. Paul D. 1.04-Fundamentals of Transport Phenomena in Polymer Membranes. In Drioli E, Giorno L, eds. Comprehensive Membrane Science and Engineering. Oxford: Elsevier, 2010, 75-90

56. Boutilier M S, Sun C, O'Hern S C, Au H, Hadjiconstantinou N G, Karnik R. Implications of permeation through intrinsic defects in graphene on the design of defect-tolerant membranes for gas separation. ACS Nano, 2014, 8(1): 841-849

57. Lin H, Freeman B D. Gas solubility, diffusivity and permeability in poly(ethylene oxide). Journal of Membrane Science, 2004, 239(1): 105-117

58. Roa F, Way J D. Influence of alloy composition and membrane fabrication on the pressure dependence of the hydrogen flux of palladiumcopper membranes. Industrial \& Engineering Chemistry Research, 2003, 42(23): 5827-5835
59. Baker R W, Lokhandwala K. Natural gas processing with membranes: an overview. Industrial \& Engineering Chemistry Research, 2008, 47(7): 2109-2121

60. Lu G, Da Costa J D, Duke M, Giessler S, Socolow R, Williams R, Kreutz $\mathrm{T}$. Inorganic membranes for hydrogen production and purification: a critical review and perspective. Journal of Colloid and Interface Science, 2007, 314(2): 589-603

61. Yun S, Ted Oyama S. Correlations in palladium membranes for hydrogen separation: a review. Journal of Membrane Science, 2011, 375(1-2): 28-45

62. Kamakoti P, Morreale B D, Ciocco M V, Howard B H, Killmeyer R P, Cugini A V, Sholl D S. Prediction of hydrogen flux through sulfur-tolerant binary alloy membranes. Science, 2005, 307(5709): 569-573

63. O'Brien C P, Howard B H, Miller J B, Morreale B D, Gellman A J. Inhibition of hydrogen transport through $\mathrm{Pd}$ and $\mathrm{Pd}_{47} \mathrm{Cu}_{53}$ membranes by $\mathrm{H}_{2} \mathrm{~S}$ at $350{ }^{\circ} \mathrm{C}$. Journal of Membrane Science, 2010, 349(1-2): 380-384

64. Kuraoka K, Zhao H, Yazawa T. Pore-filled palladium-glass composite membranes for hydrogen separation by novel electroless plating technique. Journal of Materials Science, 2004, 39(5): 1879-1881

65. Itoh N, Akiha T, Sato T. Preparation of thin palladium composite membrane tube by a CVD technique and its hydrogen permselectivity. Catalysis Today, 2005, 104(2-4): 231-237

66. Burggraaf A J. Important Characteristics of Inorganic Membranes. Amsterdam: Elsevier, 1996, 21-34

67. Collins J P, Way J D. Hydrogen selective membrane. US Patent, 5652020, 1997-07-29

68. Yan S, Maeda H, Kusakabe K, Morooka S. Thin palladium membrane formed in support pores by metal-organic chemical vapor deposition method and application to hydrogen separation. Industrial \& Engineering Chemistry Research, 1994, 33(3): 616622

69. Yun S, Ko J H, Oyama S T. Ultrathin palladium membranes prepared by a novel electric field assisted activation. Journal of Membrane Science, 2011, 369(1-2): 482-489

70. Tong J, Shirai R, Kashima Y, Matsumura Y. Preparation of a pinhole-free PdAg membrane on a porous metal support for pure hydrogen separation. Journal of Membrane Science, 2005, 260(12): $84-89$

71. Shi Z, Wu S, Szpunar J A, Roshd M. An observation of palladium membrane formation on a porous stainless steel substrate by electroless deposition. Journal of Membrane Science, 2006, 280(12): 705-711

72. Okazaki J, Tanaka D A P, Tanco M A L, Wakui Y, Mizukami F, Suzuki T M. Hydrogen permeability study of the thin PdAg alloy membranes in the temperature range across the $\alpha \beta$ phase transition. Journal of Membrane Science, 2006, 282(1-2): 370-374

73. Harris J R. Coated diffusion membrane and its use. US Patent, 4536196, 1985-08-20

74. Peters T A, Kaleta T, Stange M, Bredesen R. Development of thin binary and ternary Pd-based alloy membranes for use in hydrogen production. Journal of Membrane Science, 2011, 383(1-2): 124134

75. Peters T A, Kaleta T, Stange M, Bredesen R. Hydrogen transport 
through a selection of thin Pd-alloy membranes: membrane stability, $\mathrm{H}_{2} \mathrm{~S}$ inhibition, and flux recovery in hydrogen and simulated WGS mixtures. Catalysis Today, 2012, 193(1): 8-19

76. Nair B K R, Choi J, Harold M P. Electroless plating and permeation features of $\mathrm{Pd}$ and $\mathrm{Pd} / \mathrm{Ag}$ hollow fiber composite membranes. Journal of Membrane Science, 2007, 288(1-2): 67-84

77. Gade S K, Thoen P M, Way J D. Unsupported palladium alloy foil membranes fabricated by electroless plating. Journal of Membrane Science, 2008, 316(1-2): 112-118

78. Sanz R, Calles J A, Alique D, Furones L, Ordóñez S, Marín P, Corengia P, Fernandez E. Preparation, testing and modelling of a hydrogen selective $\mathrm{Pd} / \mathrm{YSZ} / \mathrm{SS}$ composite membrane. International Journal of Hydrogen Energy, 2011, 36(24): 15783-15793

79. Roa F, Block M J, Way J D. The influence of alloy composition on the $\mathrm{H}_{2}$ flux of composite Pd-Cu membranes. Desalination, 2002, 147(1-3): 411-416

80. Lukyanov B N, Andreev D V, Parmon V N. Catalytic reactors with hydrogen membrane separation. Chemical Engineering Journal, 2009, 154(1-3): 258-266

81. Emerson S, Magdefrau N, She Y, Thibaud Erkey C. Advanced Palladium Membrane Scale-up for Hydrogen Separation. Technical Report DEFE0004967. 2012

82. De Falco M, Iaquaniello G, Palo E, Cucchiella B, Palma V, Ciambelli P. Palladium-based membranes for hydrogen separation: preparation, economic analysis and coupling with a water gas shift reactor. In: Handbook of Membrane Reactors. Cambridge: Woodhead Publishing, 2013, 456-486

83. Rosensteel W A, Ricote S, Sullivan N P. Hydrogen permeation through dense $\mathrm{BaCe}_{0.8} \mathrm{Y}_{0.2} \mathrm{O}_{3} \delta \mathrm{Ce}_{0.8} \mathrm{Y}_{0.2} \mathrm{O}_{2} \delta$ composite-ceramic hydrogen separation membranes. International Journal of Hydrogen Energy, 2016, 41(4): 2598-2606

84. Elangovan S, Nair B, Small T, Heck B, Bay I, Timper M, Hartvigsen J, Wilson M. Ceramic membrane devices for ultra-high purity hydrogen production: mixed conducting membrane development. New York: Springer, 2009, 67-81

85. Phair J, Badwal S. Review of proton conductors for hydrogen separation. Ionics, 2006, 12(2): 103-115

86. Tao Z, Yan L, Qiao J, Wang B, Zhang L, Zhang J. A review of advanced proton-conducting materials for hydrogen separation. Progress in Materials Science, 2015, 74: 1-50

87. Fontaine M L, Norby T, Larring Y, Grande T, Bredesen R. Oxygen and hydrogen separation membranes based on dense ceramic conductors. Membrane Science and Technology, 2008, 13: 401458

88. Cardoso S P, Azenha I S, Lin Z, Portugal I, Rodrigues A E, Silva C $M$. Inorganic membranes for hydrogen separation. Separation and Purification Reviews, 2018, 47(3): 229-266

89. Lundin S T B, Patki N S, Fuerst T F, Ricote S, Wolden C A, Way J D. Dense Inorganic Membranes for Hydrogen Separation. New Jersey: World Scientific Publishing, 2017

90. Meulenberg W, Ivanova M, Serra J, Roitsch S. Proton-Conducting Ceramic Membranes for Solid Oxide Fuel Cells and Hydrogen $\left(\mathrm{H}_{2}\right)$ Processing. Amsterdam: Elsevier, 2011, 541-567

91. Tan $X$, Tan $X$, Yang N, Meng B, Zhang K, Liu S. High performance $\mathrm{BaCe}_{0.8} \mathrm{Y}_{0.2} \mathrm{O}_{3-\alpha}(\mathrm{BCY})$ hollow fibre membranes for hydrogen permeation. Ceramics International, 2014, 40(2): 3131-
3138

92. Hung I M, Chiang Y J, Jang J S C, Lin J C, Lee S W, Chang J K, Hsi C S. The proton conduction and hydrogen permeation characteristic of $\operatorname{Sr}\left(\mathrm{Ce}_{0.6} \mathrm{Zr}_{0.4}\right)_{0.85} \mathrm{Y}_{0.15} \mathrm{O}_{3-\delta}$ ceramic separation membrane. Journal of the European Ceramic Society, 2015, 35(1): 163-170

93. Mather G C, Poulidi D, Thursfield A, Pascual M J, Jurado J R, Metcalfe I S. Hydrogen-permeation characteristics of a $\mathrm{SrCeO}_{3}$ based ceramic separation membrane: thermal, ageing and surfacemodification effects. Solid State Ionics, 2010, 181(3-4): 230-235

94. Omata T, Otsuka Yao Matsuo S. Infrared absorption spectra of high temperature proton conducting $\mathrm{Ca}^{2+}$-doped $\mathrm{La}_{2} \mathrm{Zr}_{2} \mathrm{O}_{7}$. Journal of the Electrochemical Society, 2001, 148(12): 475-482

95. Hamakawa S, Li L, Li A, Iglesia E. Synthesis and hydrogen permeation properties of membranes based on dense $\mathrm{SrCe}_{0.95} \mathrm{Yb}_{0.05} \mathrm{O}_{3-\alpha}$ thin films. Solid State Ionics, 2002, 148(1-2): $71-81$

96. Tong J, Su L, Haraya K, Suda H. Thin and defect-free Pd-based composite membrane without any interlayer and substrate penetration by a combined organic and inorganic process. Chemical Communications, 2006, (10): 1142-1144

97. Escolástico S, Somacescu S, Serra J M. Tailoring mixed ionicelectronic conduction in $\mathrm{H}_{2}$ permeable membranes based on the system $\mathrm{Nd}_{5.5} \mathrm{~W}_{1-x} \mathrm{Mo}_{x} \mathrm{O}_{11.25-\delta}$. Journal of Materials Chemistry. A, Materials for Energy and Sustainability, 2015, 3(2): 719731

98. Chen Y, Cheng S, Chen L, Wei Y, Ashman P J, Wang H. Niobium and molybdenum co-doped $\mathrm{La}_{5.5} \mathrm{WO}_{11.25-\delta}$ membrane with improved hydrogen permeability. Journal of Membrane Science, 2016, 510: 155-163

99. Zhu Z, Sun W, Wang Z, Cao J, Dong Y, Liu W. A high stability $\mathrm{NiLa}_{0.5} \mathrm{Ce}_{0.5} \mathrm{O}_{2-\delta}$ asymmetrical metalceramic membrane for hydrogen separation and generation. Journal of Power Sources, 2015, 281: 417-424

100. Balachandran U, Lee T, Chen L, Song S, Picciolo J, Dorris S. Hydrogen separation by dense cermet membranes. Fuel, 2006, 85 (2): 150-155

101. Meng X, Song J, Yang N, Meng B, Tan X, Ma Z F, Li K. $\mathrm{NiBaCe}_{0.95} \mathrm{~Tb}_{0.05} \mathrm{O}_{3-\delta}$ cermet membranes for hydrogen permeation. Journal of Membrane Science, 2012, 401: 300-305

102. Rebollo E, Mortalò C, Escolástico S, Boldrini S, Barison S, Serra J M, Fabrizio M. Exceptional hydrogen permeation of all-ceramic composite robust membranes based on $\mathrm{BaCe}_{0.65} \mathrm{Zr}_{0.20} \mathrm{Y}_{0.15} \mathrm{O}_{3-\delta}$ and Y-or Gd-doped ceria. Energy \& Environmental Science, 2015, 8(1-2): 3675-3686

103. Chiu W V, Park I S, Shqau K, White J C, Schillo M C, Ho W S W, Dutta P K, Verweij H. Post-synthesis defect abatement of inorganic membranes for gas separation. Journal of Membrane Science, 2011, 377(1): 182-190

104. Xu S, Zhang X, Cheng D, Chen F, Ren X. Effect of hierarchical ZSM-5 zeolite crystal size on diffusion and catalytic performance of $n$-heptane cracking. Frontiers of Chemical Science and Engineering, 2018, 12(4): 780-789

105. Ye Z, Zhang H, Zhang Y, Tang Y. Seedinduced synthesis of functional MFI zeolite materials: method development, crystallization mechanisms and catalytic properties. Frontiers of Chemi- 
cal Science and Engineering, 2019: 1-16

106. Huang A, Wang N, Caro J. Synthesis of multi-layer zeolite LTA membranes with enhanced gas separation performance by using 3-aminopropyltriethoxysilane as interlayer. Microporous and Mesoporous Materials, 2012, 164: 294-301

107. Huang A, Wang N, Caro J. Seeding-free synthesis of dense zeolite FAU membranes on 3-aminopropyltriethoxysilane-functionalized alumina supports. Journal of Membrane Science, 2012, 389: 272279

108. Tang Z, Dong J, Nenoff T M. Internal surface modification of MFI-type zeolite membranes for high selectivity and high flux for hydrogen. Langmuir, 2009, 25(9): 4848-4852

109. Shafie A H, An W, Hosseinzadeh Hejazi S A, Sawada J A, Kuznicki S M. Natural zeolite-based cement composite membranes for $\mathrm{H}_{2} / \mathrm{CO}_{2}$ separation. Separation and Purification Technology, 2012, 88: 24-28

110. Prabhu A K, Oyama S T. Highly hydrogen selective ceramic membranes: application to the transformation of greenhouse gases. Journal of Membrane Science, 2000, 176(2): 233-248

111. Tsuru T. Development of metal-doped silica membranes for increased hydrothermal stability and their applications to membrane reactors for steam reforming of methane. Journal of the Japan Petroleum Institute, 2011, 54(5): 277-286

112. Fan J, Ohya H, Suga T, Ohashi H, Yamashita K, Tsuchiya S, Aihara M, Takeuchi T, Negishi Y. High flux zirconia composite membrane for hydrogen separation at elevated temperature. Journal of Membrane Science, 2000, 170(1): 113-125

113. Koresh J E, Soffer A. The carbon molecular sieve membranes: general properties and the permeability of $\mathrm{CH}_{4} / \mathrm{H}_{2}$ mixture. Separation Science and Technology, 1987, 22(2-3): 973-982

114. Vieira-Linhares A M, Seaton N A. Non-equilibrium molecular dynamics simulation of gas separation in a microporous carbon membrane. Chemical Engineering Science, 2003, 58(18): 41294136

115. Saufi S M, Ismail A F. Fabrication of carbon membranes for gas separation: a review. Carbon, 2004, 42(2): 241-259

116. Jiang D E, Cooper V R, Dai S. Porous graphene as the ultimate membrane for gas separation. Nano Letters, 2009, 9(12): 40194024

117. Wang Q, O'Hare D. Recent advances in the synthesis and application of layered double hydroxide (LDH) nanosheets. Chemical Reviews, 2012, 112(7): 4124-4155

118. Lu P, Liu Y, Zhou T, Wang Q, Li Y. Recent advances in layered double hydroxides (LDHs) as two-dimensional membrane materials for gas and liquid separations. Journal of Membrane Science, 2018, 567: 89-103

119. Liu Y, Wang N, Caro J. In situ formation of LDH membranes of different microstructures with molecular sieve gas selectivity. Journal of Materials Chemistry. A, Materials for Energy and Sustainability, 2014, 2(16): 5716-5723

120. Liu Y, Peng Y, Wang N, Li Y, Pan J H, Yang W, Caro J. Significantly enhanced separation using ZIF-8 membranes by partial conversion of calcined layered double hydroxide precursors. ChemSusChem, 2015, 8(21): 3582-3586

121. Ranjan R, Tsapatsis M. Microporous metal organic framework membrane on porous support using the seeded growth method.
Chemistry of Materials, 2009, 21(20): 4920-4924

122. Huang A, Dou W, Caro J R. Steam-stable zeolitic imidazolate framework ZIF-90 membrane with hydrogen selectivity through covalent functionalization. Journal of the American Chemical Society, 2010, 132(44): 15562-15564

123. Zhang F, Zou X, Gao X, Fan S, Sun F, Ren H, Zhu G. Hydrogen selective $\mathrm{NH}_{2}$-MIL-53 (Al) MOF membranes with high permeability. Advanced Functional Materials, 2012, 22(17): 3583-3590

124. Brown A J, Brunelli N A, Eum K, Rashidi F, Johnson J, Koros W J, Jones C W, Nair S. Interfacial microfluidic processing of metalorganic framework hollow fiber membranes. Science, 2014, 345 (6192): 72-75

125. Sutrisna P D, Savitri E, Himma N F, Prasetya N, Wenten I G. Current perspectives and mini review on zeolitic imidazolate framework-8 (ZIF-8) membranes on organic substrates. IOP Conference Series. Materials Science and Engineering, 2019, 703(1): 012045

126. Dong J, Lin Y, Liu W. Multicomponent hydrogen/hydrocarbon separation by MFI-type zeolite membranes. AIChE Journal, 2000, 46(10): 1957-1966

127. Poshusta J C, Tuan V A, Falconer J L, Noble R D. Synthesis and permeation properties of SAPO-34 tubular membranes. Industrial \& Engineering Chemistry Research, 1998, 37(10): 3924-3929

128. Liu B S, Au C T. A $\mathrm{La}_{2} \mathrm{NiO}_{4}$-zeolite membrane reactor for the $\mathrm{CO}_{2}$ reforming of methane to syngas. Catalysis Letters, 2001, 77(1-3): $67-74$

129. Lee D, Zhang L, Oyama S, Niu S, Saraf R F. Synthesis, characterization and gas permeation properties of a hydrogen permeable silica membrane supported on porous alumina. Journal of Membrane Science, 2004, 231(1-2): 117-126

130. Moon J H, Bae J H, Bae Y S, Chung J T, Lee C H. Hydrogen separation from reforming gas using organic templating silica/ alumina composite membrane. Journal of Membrane Science, 2008, 318(1-2): 45-55

131. Gu Y, Oyama S T. Ultrathin, hydrogen-selective silica membranes deposited on alumina-graded structures prepared from sizecontrolled boehmite sols. Journal of Membrane Science, 2007, 306(1-2): 216-227

132. Jones C W, Koros W J. Carbon molecular sieve gas separation membranes-I. Preparation and characterization based on polyimide precursors. Carbon, 1994, 32(8): 1419-1425

133. Petersen J, Matsuda M, Haraya K. Capillary carbon molecular sieve membranes derived from Kapton for high temperature gas separation. Journal of Membrane Science, 1997, 131(1-2): 85-94

134. Wei W, Hu H, You L, Chen G. Preparation of carbon molecular sieve membrane from phenol-formaldehyde Novolac resin. Carbon, 2002, 40(3): 465-467

135. Kusuki Y, Shimazaki H, Tanihara N, Nakanishi S, Yoshinaga T. Gas permeation properties and characterization of asymmetric carbon membranes prepared by pyrolyzing asymmetric polyimide hollow fiber membrane. Journal of Membrane Science, 1997, 134 (2): $245-253$

136. Tanihara N, Shimazaki H, Hirayama Y, Nakanishi S, Yoshinaga T, Kusuki Y. Gas permeation properties of asymmetric carbon hollow fiber membranes prepared from asymmetric polyimide hollow fiber. Journal of Membrane Science, 1999, 160(2): 179-186 
137. Kita H, Yoshino M, Tanaka K, Okamoto K. Gas permselectivity of carbonized polypyrrolone membrane. Chemical Communications, 1997, (11): 1051-1052

138. Guo H, Zhu G, Hewitt I J, Qiu S. "Twin copper source” growth of metalorganic framework membrane: $\mathrm{Cu}_{3}(\mathrm{BTC})_{2}$ with high permeability and selectivity for recycling $\mathrm{H}_{2}$. Journal of the American Chemical Society, 2009, 131(5): 1646-1647

139. Bux H, Liang F, Li Y, Cravillon J, Wiebcke M, Caro J R. Zeolitic imidazolate framework membrane with molecular sieving properties by microwave-assisted solvothermal synthesis. Journal of the American Chemical Society, 2009, 131(44): 16000-16001

140. Huang A, Chen Y, Wang N, Hu Z, Jiang J, Caro J. A highly permeable and selective zeolitic imidazolate framework ZIF-95 membrane for $\mathrm{H}_{2} / \mathrm{CO}_{2}$ separation. Chemical Communications, 2012, 48(89): 10981-10983

141. Lee D J, Li Q, Kim H, Lee K. Preparation of Ni-MOF-74 membrane for $\mathrm{CO}_{2}$ separation by layer-by-layer seeding technique. Microporous and Mesoporous Materials, 2012, 163: 169-177

142. Sanders D F, Smith Z P, Guo R, Robeson L M, McGrath J E, Paul D R, Freeman B D. Energy-efficient polymeric gas separation membranes for a sustainable future: a review. Polymer, 2013, 54 (18): 4729-4761

143. Ekiner O, Vassilatos G. Polyaramide hollow fibers for hydrogen/ methane separation - spinning and properties. Journal of Membrane Science, 1990, 53(3): 259-273

144. Robeson L M. Correlation of separation factor versus permeability for polymeric membranes. Journal of Membrane Science, 1991, 62 (2): 165-185

145. Robeson L M. The upper bound revisited. Journal of Membrane Science, 2008, 320(1-2): 390-400

146. Esposito E, Mazzei I, Monteleone M, Fuoco A, Carta M, McKeown N, Malpass Evans R, Jansen J. Highly permeable matrimid $^{\circledR} /$ PIM-EA $\left(\mathrm{H}_{2}\right)$-TB blend membrane for gas separation. Polymers, 2018, 11(1): 46

147. McKeown N B, Budd P M. Polymers of intrinsic microporosity (PIMs): organic materials for membrane separations, heterogeneous catalysis and hydrogen storage. Chemical Society Reviews, 2006, 35(8): 675-683

148. Li F Y, Xiao Y, Chung T S, Kawi S. High-performance thermally self-cross-linked polymer of intrinsic microporosity (PIM-1) membranes for energy development. Macromolecules, 2012, 45 (3): $1427-1437$

149. Kim S, Lee Y M. Rigid and microporous polymers for gas separation membranes. Progress in Polymer Science, 2015, 43: 132

150. Park H B, Jung C H, Lee Y M, Hill A J, Pas S J, Mudie S T, Van Wagner E, Freeman B D, Cookson D J. Polymers with cavities tuned for fast selective transport of small molecules and ions. Science, 2007, 318(5848): 254-258

151. Han S H, Lee J E, Lee K J, Park H B, Lee Y M. Highly gas permeable and microporous polybenzimidazole membrane by thermal rearrangement. Journal of Membrane Science, 2010, 357 (1-2): 143-151

152. Han S H, Misdan N, Kim S, Doherty C M, Hill A J, Lee Y M. Thermally rearranged (TR) polybenzoxazole: effects of diverse imidization routes on physical properties and gas transport behaviors. Macromolecules, 2010, 43(18): 7657-7667

153. Yeong Y F, Wang H, Pallathadka Pramoda K, Chung T S. Thermal induced structural rearrangement of cardo-copolybenzoxazole membranes for enhanced gas transport properties. Journal of Membrane Science, 2012, 397: 51-65

154. Zornoza B, Téllez C, Coronas J, Esekhile O, Koros W J. Mixed matrix membranes based on 6FDA polyimide with silica and zeolite microsphere dispersed phases. AIChE Journal, 2015, 61 (12): 4481-4490

155. Safak Boroglu M, Yumru A B. Gas separation performance of 6FDA-DAM-ZIF-11 mixed-matrix membranes for $\mathrm{H}_{2} / \mathrm{CH}_{4}$ and $\mathrm{CO}_{2} / \mathrm{CH}_{4}$ separation. Separation and Purification Technology, 2017, 173: 269-279

156. Kim E, Kim H, Kim D, Kim J, Lee P. Preparation of mixed matrix membranes containing ZIF-8 and UiO-66 for multicomponent light gas separation. Crystals, 2019, 9(1): 15

157. Weng T H, Tseng H H, Wey M Y. Preparation and characterization of multi-walled carbon nanotube/PBNPI nanocomposite membrane for $\mathrm{H}_{2} / \mathrm{CH}_{4}$ separation. International Journal of Hydrogen Energy, 2009, 34(20): 8707-8715

158. Xie K, Fu Q, Xu C, Lu H, Zhao Q, Curtain R, Gu D, Webley P A, Qiao G G. Continuous assembly of a polymer on a metalorganic framework (CAP on MOF): a $30 \mathrm{~nm}$ thick polymeric gas separation membrane. Energy \& Environmental Science, 2018, 11(3): 544-550

159. Hu G, Chen C, Lu H T, Wu Y, Liu C, Tao L, Men Y, He G, Li G. A review of technical advances, barriers and solutions in the power to gas (P2G) roadmap. Engineering, 2020, (in press)

160. APA Group. Gas Specification for Roma-Brisbane Pipeline. 2010

161. De Wild P, Nyquist R, De Bruijn F, Stobbe E. Removal of sulphurcontaining odorants from fuel gases for fuel cell-based combined heat and power applications. Journal of Power Sources, 2006, 159 (2): 995-1004

162. Golebiowska M, Roth M, Firlej L, Kuchta B, Wexler C. The reversibility of the adsorption of methanemethyl mercaptan mixtures in nanoporous carbon. Carbon, 2012, 50(1): 225-234

163. Farrauto R J. Introduction to solid polymer membrane fuel cells and reforming natural gas for production of hydrogen. Applied Catalysis B: Environmental, 2005, 56(1-2): 3-7

164. Peters T A, Stange M, Veenstra P, Nijmeijer A, Bredesen R. The performance of $\mathrm{PdAg}$ alloy membrane films under exposure to trace amounts of $\mathrm{H}_{2} \mathrm{~S}$. Journal of Membrane Science, 2016, 499 : 105-115

165. De Nooijer N, Sanchez J D, Melendez J, Fernandez E, Pacheco Tanaka D A, Van Sint Annaland M, Gallucci F. Influence of $\mathrm{H}_{2} \mathrm{~S}$ on the hydrogen flux of thin-film PdAgAu membranes. International Journal of Hydrogen Energy, 2020, 45(12): 7303-7312

166. Fotou G, Lin Y, Pratsinis S E. Hydrothermal stability of pure and modified microporous silica membranes. Journal of Materials Science, 1995, 30(11): 2803-2808

167. Uhlmann D, Smart S, Diniz Da Costa J C H. 2S stability and separation performance of cobalt oxide silica membranes. Journal of Membrane Science, 2011, 380(1-2): 48-54

168. de Vos R M, Maier W F, Verweij H. Hydrophobic silica membranes for gas separation. Journal of Membrane Science, 1999, 158(1-2): 277-288 
169. Wei Q, Ding Y L, Nie Z R, Liu X G, Li Q Y. Wettability, pore structure and performance of perfluorodecyl-modified silica membranes. Journal of Membrane Science, 2014, 466: 114-122

170. Glass R W, Ross R A. Surface studies of the adsorption of sulfurcontaining gases at 423.deg.K on porus adsorbents. II. Adsorption of hydrogen sulfide, methanethiol, ethanethiol and dimethyl sulfide on gamma.-alumina. Journal of Physical Chemistry, 1973, 77(21): 2576-2578

171. Akamatsu K, Nakane M, Sugawara T, Hattori T, Nakao S. Development of a membrane reactor for decomposing hydrogen sulfide into hydrogen using a high-performance amorphous silica membrane. Journal of Membrane Science, 2008, 325(1): 16-19

172. Schell W, Wensley C, Chen M, Venugopal K, Miller B, Stuart J. Recent advances in cellulosic membranes for gas separation and pervaporation. Gas Separation \& Purification, 1989, 3(4): 162169

173. Lu H, Kanehashi S, Scholes C, Kentish S. The impact of ethylene glycol and hydrogen sulphide on the performance of cellulose triacetate membranes in natural gas sweetening. Journal of Membrane Science, 2017, 539: 432-440

174. Plaisance C P, Dooley K M. Zeolite and metal oxide catalysts for the production of dimethyl sulfide and methanethiol. Catalysis Letters, 2009, 128(3-4): 449-458

175. Walker S B, Mukherjee U, Fowler M, Elkamel A. Benchmarking and selection of power-to-gas utilizing electrolytic hydrogen as an energy storage alternative. International Journal of Hydrogen Energy, 2016, 41(19): 7717-7731
176. Lubitz W, Tumas W. Hydrogen: an overview. Chemical Reviews, 2007, 107(10): 3900-3903

177. Iulianelli A, Drioli E. Membrane engineering: latest advancements in gas separation and pre-treatment processes, petrochemical industry and refinery, and future perspectives in emerging applications. Fuel Processing Technology, 2020, 206: 106464

178. Coker D, Freeman B, Fleming G. Modeling multicomponent gas separation using hollowfiber membrane contactors. AIChE Journal. American Institute of Chemical Engineers, 1998, 44(6): $1289-1302$

179. Kundu P K, Chakma A, Feng X. Simulation of binary gas separation with asymmetric hollow fibre membranes and case studies of air separation. Canadian Journal of Chemical Engineering, 2012, 90(5): 1253-1268

180. Soroodan Miandoab E, Kentish S E, Scholes C A. Non-ideal modelling of polymeric hollow-fibre membrane systems: precombustion $\mathrm{CO}_{2}$ capture case study. Journal of Membrane Science, 2020, 595: 117470

181. Franz J, Scherer V. An evaluation of $\mathrm{CO}_{2}$ and $\mathrm{H}_{2}$ selective polymeric membranes for $\mathrm{CO}_{2}$ separation in IGCC processes. Journal of Membrane Science, 2010, 359(1-2): 173-183

182. Basile A, Dalena F, Tong J, Veziroğlu T N. Hydrogen Production, Separation and Purification for Energy. London: The Insititution of Engineering and Technology, 2017

183. Liemberger W, Halmschlager D, Miltner M, Harasek M. Efficient extraction of hydrogen transported as co-stream in the natural gas grid - the importance of process design. Applied Energy, 2019, 233-234: 747-763 